\title{
A Cumulative Biological Assessment of Macroinvertebrate Sites in the Custer National Forest Ashland Ranger District
}

\section{A Report to the Custer National Forest, Ashland Ranger District}

\author{
David Stagliano
}

Montana Natural Heritage Program

Helena, Montana

February 2010

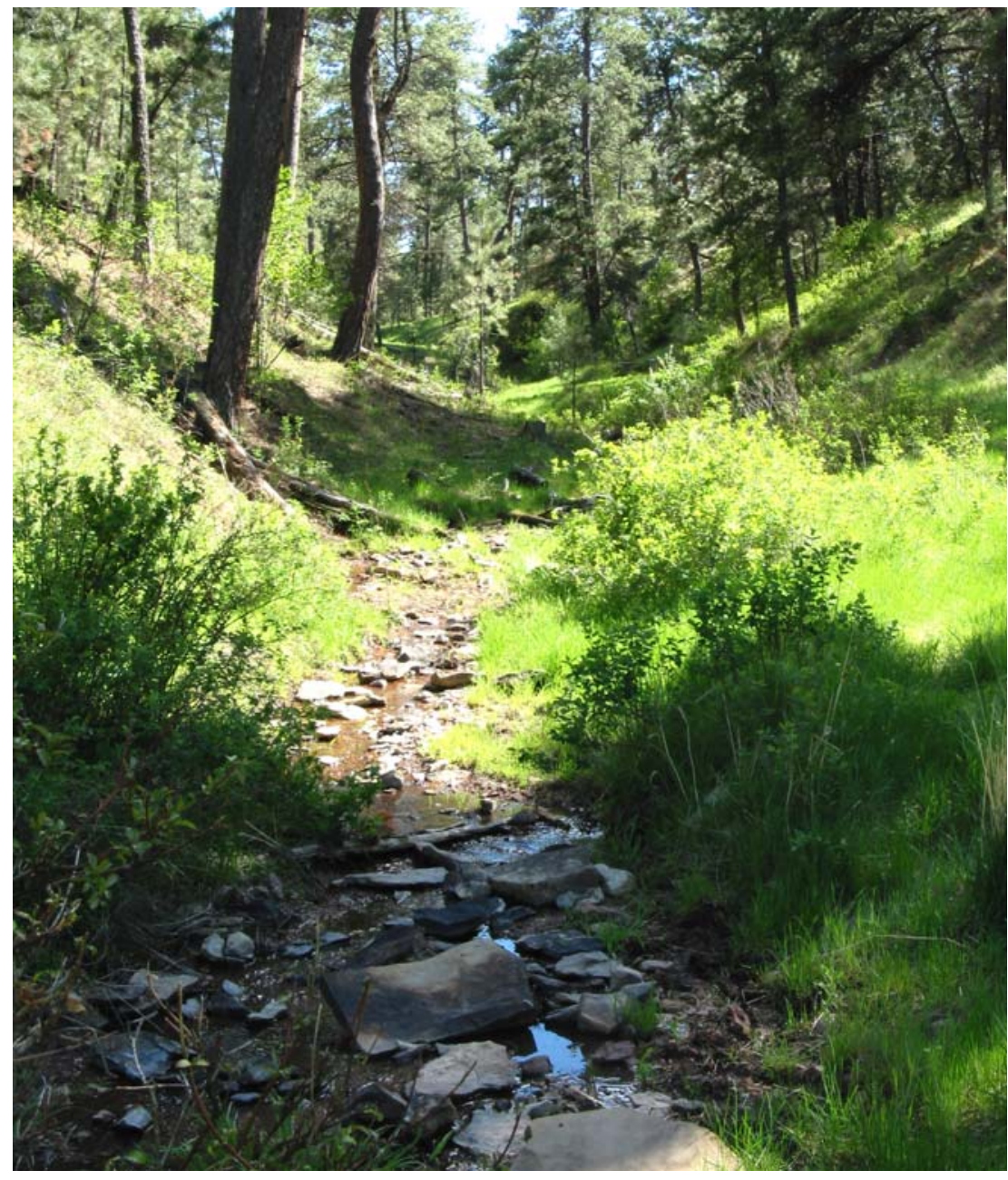

Natural Heritage

Program

Natural Resource Information System Montana State Library 


\section{ACKNOWLEDGEMENTS}

We would like to thank Don Sasse of the Ashland District of the Custer National Forest and Darin Watschke, Custer Fisheries Biologist for support and funding of Amphibian \& Aquatic Projects of MTNHP. This project was funded through an ongoing agreement USFS Region 1 Amphibian Inventory Project: 05-CS-11015600-036 established with great foresight by Ann Carlson and Bryce Maxell. We wish to thank those who assisted us in the field during the course of this project; including Don Sasse, Matt Gates, Ryan Killackey, Kief Storrar, Eric Diallio and others on the amphibian crew. Meghan Burns produced the sample maps and Amandi Standley helped process some of the aquatic macroinvertebrate samples.

All photos in the report were taken by MTNHP personnel, unless otherwise noted. 


\section{Executive Summary}

The objectives of this study were to: 1) Compile all aquatic macroinvertebrate survey sites within the Custer National Forest (Ashland Ranger District) as a continuing baseline survey and biological assessment; 2) Complete identification and analysis of macroinvertebrate samples collected in 2005 and 2006 that were not processed, 3) test the temporal stability of small spring macroinvertebrate metrics with multiple revisits to established reference sites; 4) Compile all sites sampled from 2004 to present into a comprehensive table of impaired and non-impaired reaches based on habitat and macroinvertebrate metrics; 4) Evaluate management practices that will benefit the long-term sustainability of community integrity at these sites (i.e., cattle exclusion fences, shorter rotational grazing). The goal of this inventory work is to facilitate the Regional Restoration Strategy by filling in gaps in existing data, locating rare elements on the landscape, and identifying opportunities for restoration and management actions.

Riparian habitat assessments and macroinvertebrate surveys were performed at 52 lotic (spring/stream) sites and 26 lentic (prairie pools/stock pond/reservior) sites within the Ashland District from 2004-2008. Four stream sites (3 spatially identical reaches and 1 site upstream $~ 50 \mathrm{~m}$ ) were revisited from 2004 to 2008 (Cow Creek upstream of the reservoir has 4 years of monitoring data) to evaluate the temporal stability of macroinvertebrate metrics for determining biological integrity.

Macroinvertebrate Communities: Overall, 132 macroinvertebrate taxa were collected from all sites between 2004-2008 but no USFS species of concern (SOC) or species of interest (SOI) were discovered. A unique caddisfly, Philarctus quaeris that produces its case from snail shells was found in the Little Bear Creek pools in 2008; this permanent pool site maintains a high diversity of macroinvertebrates (32 taxa), including 5 snail species and many aquatic beetle taxa. The only stonefly taxa (Amphinemura cf. banksi) reported in the Ashland District was found at 3 of the most intact spring systems. Average macroinvertebrate taxa richness per lotic and lentic sites was 20 and 16, respectively, and the highest taxa richness reported was 53 at the Otter Creek 2004 site and 38 taxa at 2 spring sites. Using MT DEQ's macroinvertebrate multimetric index (MMI) and the Spring Reference Indicator (O/E), 4 of the 52 lotic sites were ranked non-impaired (excellent biological integrity), 12 were slightly-impaired, 24 were moderately-impaired and 11 severely degraded. Cow Creek above reservoir, Parrish Spring, Prune (Charcoal) Creek Spring and Stocker Branch contain reference condition lotic spring macroinvertebrate communities. While there is no current standardized method for analyzing lentic macroinvertebrates, Cow Creek Reservoir, Mud Turtle Reservoir, and Poker Jim Pond contain highly diverse lentic macroinvertebrate communities, including 5 dragonfly and 5 damselfly species. Cow Creek Reservoir also remains the hotspot for herpetofauna with 5 species reported. In 2008, we sampled 26 sites for macroinvertebrates: 2 of these were site revisits (Cow Creek, Stocker Branch). Taylor Creek, O’Dell, Hazel Creek and Poker Jim Reservoirs were sampled for macroinvertebrates during the 2005 field season and were processed for this report with the additional funding.

Community Integrity results from the habitat and macroinvertebrate surveys combined to rank the Cow Creek reach upstream of Cow Creek Reservoir the most ecologically intact site and the reference condition Northwestern Great Plains Spring Ecological System for the Ashland area, followed by Parrish Spring (2008), Prune Spring (2005), Stocker Branch Spring (2004), and the Charcoal Creek (Prune Spring) 2004 site. Lentic (stock ponds) sites with high macroinvertebrate diversity include Cow Creek Reservoir, Mud Turtle Reservoir and Poker Jim Reservoirs. We recommend choosing these as integrator and future monitoring sites and should be managed for their high diversity and integrity as Northwestern Great Plains Perennial Spring ecosystems. Additional sites that have high ecological potential to recover if cattle exclusion occurs include lower Charcoal Creek, Cow Creek below the reservoir, Davis Prong of EF Hanging Woman, Little Brian Spring \#1, Brian Spring \#2, Ash Creek Spring and Black Canyon Reservoir Spring. 


\section{TABLE OF CONTENTS}

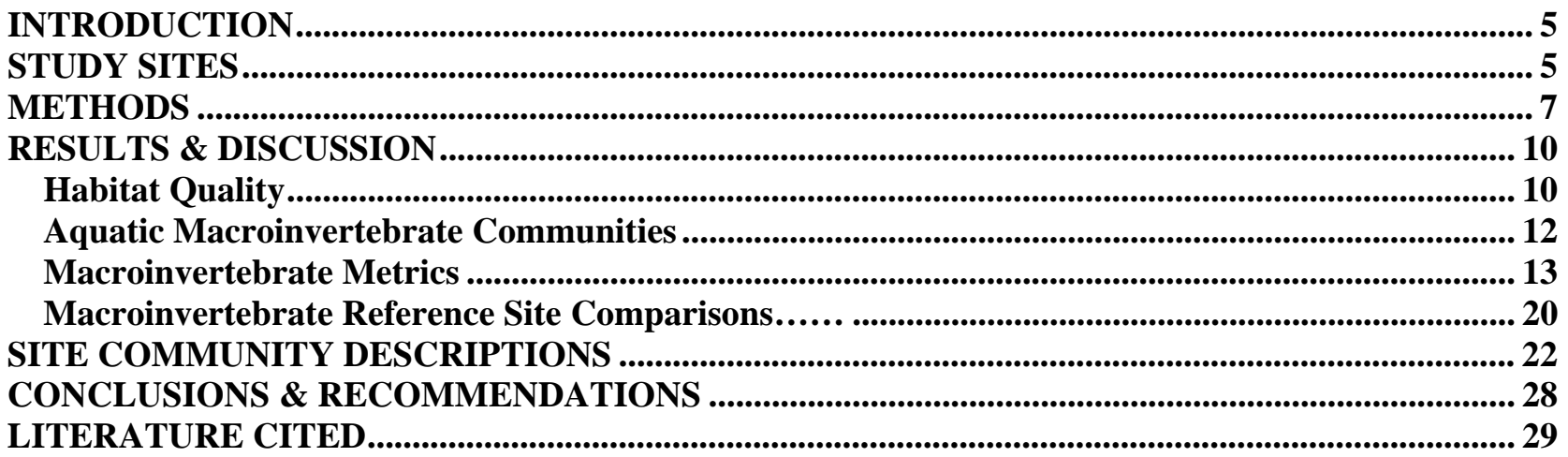

Appendix A. Macroinvertebrate Integrity of sites sampled within the Ashland District Custer Forest Appendix B. Macroinvertebrate Taxa Lists and MMI data for select reference sites and revisits. Appendix C. Northwestern Great Plains Perennial Spring Ecological Description.

\section{List of Figures}

Figure 1. Spatial distribution of macroinvertebrate sites within the Ashland District of the Custer

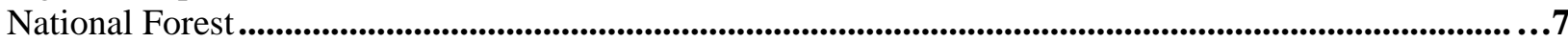

Figure 2. Macroinvertebrate sites sampled and biointegrity rankings from $2004 \ldots \ldots \ldots \ldots \ldots \ldots \ldots \ldots . \ldots 8$

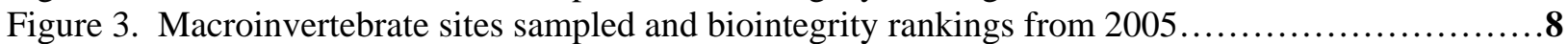

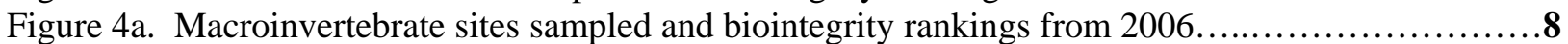

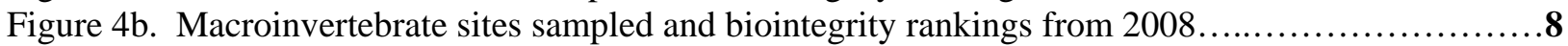

Figure 5. Picture of caddisfly, Philarctus quearis from the Little Bear Pools.......................................13

Figure 6. Picture of caddisfly, Hesperophylax designatus from Parrish Spring ..........................................13

Figure 7. Sites with NWGP Spring S005 Indicator Taxa...............................................................................13

Figure 8. Site Revisits during the 2004-2008 study. MMI Score is the DEQ 1998 model..................15

\section{List of Tables}

Table 1a. Metrics used in 1998 MMI biocriteria and the scoring criteria............................10

Table 1b. Assignment of impairment classification based on metric performance.......................10

Table 2. Impairment determinations from the 2006 MT DEQ MMI and O/E ........................11

Table 3. Reference NWGP Spring indicator species taxa list.....................................14

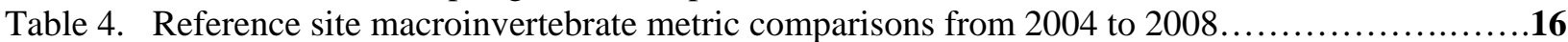




\section{INTRODUCTION}

In arid or semi-arid regions, spring ecosystems are often the only permanent water source in the uplands, providing essential habitat for myriad aquatic and terrestrial organisms (Erman 2002, Meyers and Resh 2002). They have evolved within a narrow set of environmental conditions strictly dependent on groundwater discharge (Shepard 1993), and can contain truly unique invertebrate fauna compared to surrounding habitats (Perla and Stevens 2003, Sada et al. 2005, Stagliano 2008). Riparian areas adjacent to springs can provide habitat to up to $75 \%$ of the available species diversity in arid regions (Shepard 1993). Unfortunately, in the last 200 years, cultivation, livestock grazing and other anthropogenic activities have destroyed $80 \%$ of the riparian corridors along North American and European streams and other water bodies (Naiman and Dechamps 1997). Riparian zones are not only highly diverse ecotones (Naiman et al. 1993, Manguson 1999), but present the last interface before particles and terrestrial inputs enter the aquatic ecosystem (Wenger 1999). Human-induced landscape changes may be the greatest contributing factor for the decline of our ecological resources, especially our aquatic ecosystems. Habitat destruction and alteration of the physical structure of the habitat is one of the five biggest threats to aquatic ecosystem health and biodiversity (Karr and Chu 1999).

Dramatic alterations of the quality of the watershed landscape will degrade the stream ecosystem it is spatially connected with, including the biological communities (Allen et al. 1999). Within disturbed catchments, a naturally vegetated, intact riparian zone is viewed as critical to maintaining the biological integrity of the stream ecosystem (Gregory et al. 1991). Restoration of watershed conditions to a pre-human impact state is virtually impossible in most aquatic systems (USEPA 1998). A more practical water quality goal would be to reduce the frequency and intensity of disturbances in the watershed. To maintain aquatic habitat integrity, 10-30 meters (35-100ft) of native riparian buffer should be preserved along all streams, including intermittent and ephemeral channels (Wenger 1999). In a study of Michigan rivers, the number of upstream disruptions to the riparian corridor was more important than the width of the vegetated riparian zone (Goforth et al. 2002). In heavily grazed areas of the west, fenced areas that restricted animals from the riparian zone showed improved stream bank integrity and far less bank failure, thus minimizing erosion (Beschta \& Platts 1986). 
Aquatic macroinvertebrates and fishes are commonly used as bioindicators of ecosystem health, because their abundance, diversity, presence or absence, and community structure are greatly influenced by water and habitat quality (Barbour et al. 1999). Benthic macroinvertebrate biomonitoring has become a ubiquitous practice among aquatic scientists and watershed managers (EPA 2004). As our knowledge of macroinvertebrate tolerance levels to certain stressors expands, we are better able to make causal inferences when shifts in the community occur. In a Montana aquatic community classification project, Stagliano (2005) defined the Northwestern Great Plains (NWGP) Perennial Spring ecological system, and derived the expected macroinvertebrate communities of reference and degraded stream types. Many of these NWGP perennial spring sites were described from sites sampled in a study performed on the Custer National Forest in 2004 (Stagliano 2004). MT DEQ does not specifically address this ecological system in their macroinvertebrate water quality critieria (Feldman et al. 2006); therefore, an Observed/Expected Score was developed for use in springs of the Northwestern Great Plains.

This current study reports on the structure, function and integrity of aquatic communities associated with selected perennial springs and other aquatic habitats of the Ashland District of the Custer National Forest. We examine macroinvertebrate communities in the context of habitat and biological integrity, and the presence of species of special concern (eg. USFS sensitive species) or reference spring ecosystem indicator species (S005 indicators, Stagliano et al. 2006). Future inventory surveys should focus on sampling other spring sites, identifying additional reference sites and monitoring sites with effective management of cattle grazing (i.e. fencing) along riparian areas.

\section{STUDY SITES}

Seventy-eight aquatic sites, both lotic and lentic (Figure 1, Appendix A) were visited during the course of the multi-year macroinvertebrate study; they were chosen with the help of Don Sasse and augmented with our previous experience on the forest. Sites were also screened for the presence of water and accessibility to National Forest Lands. In 2004, 12 sites were sampled (Figure 2). In 2005, 37 total sites were visited (Figure 3); of these 24 stream sites sampled, four (Charcoal, Cow Creek upper and lower, and Otter Creek) were sampled in 2004 and were compared for community stability across time (Stagliano et al. 2006). We additionally sampled Cow Creek upper in 2006 (Figure 4a) and 2008. Twenty-six sites were visited in 2008 (Figure 4b). Streams and springs flowing west and northwest to the Tongue 
River include Ash, Beaver, Charcoal, Davis Prong of East Hanging Woman, Parrish, Prune, and Stocker Branch. Those flowing east, Cow, Tooley, Little Bear, Brian, Paget and Stag Rock Springs, are tributaries to Otter Creek, which flows into the Tongue River ( $\sim 20$ river miles downstream) at the town of Ashland. Bloom Creek is a Powder River trib and Liscom Butte Sites are in the Pumpkin Creek watershed. Most sites have been described previously, but some of the newer 2008 sites sampled will be addressed in the Site Descriptions.

Figure 1. Spatial distribution and biointegrity of all macroinvertebrate sites sampled (20042008) within the Ashland District of the Custer National Forest.

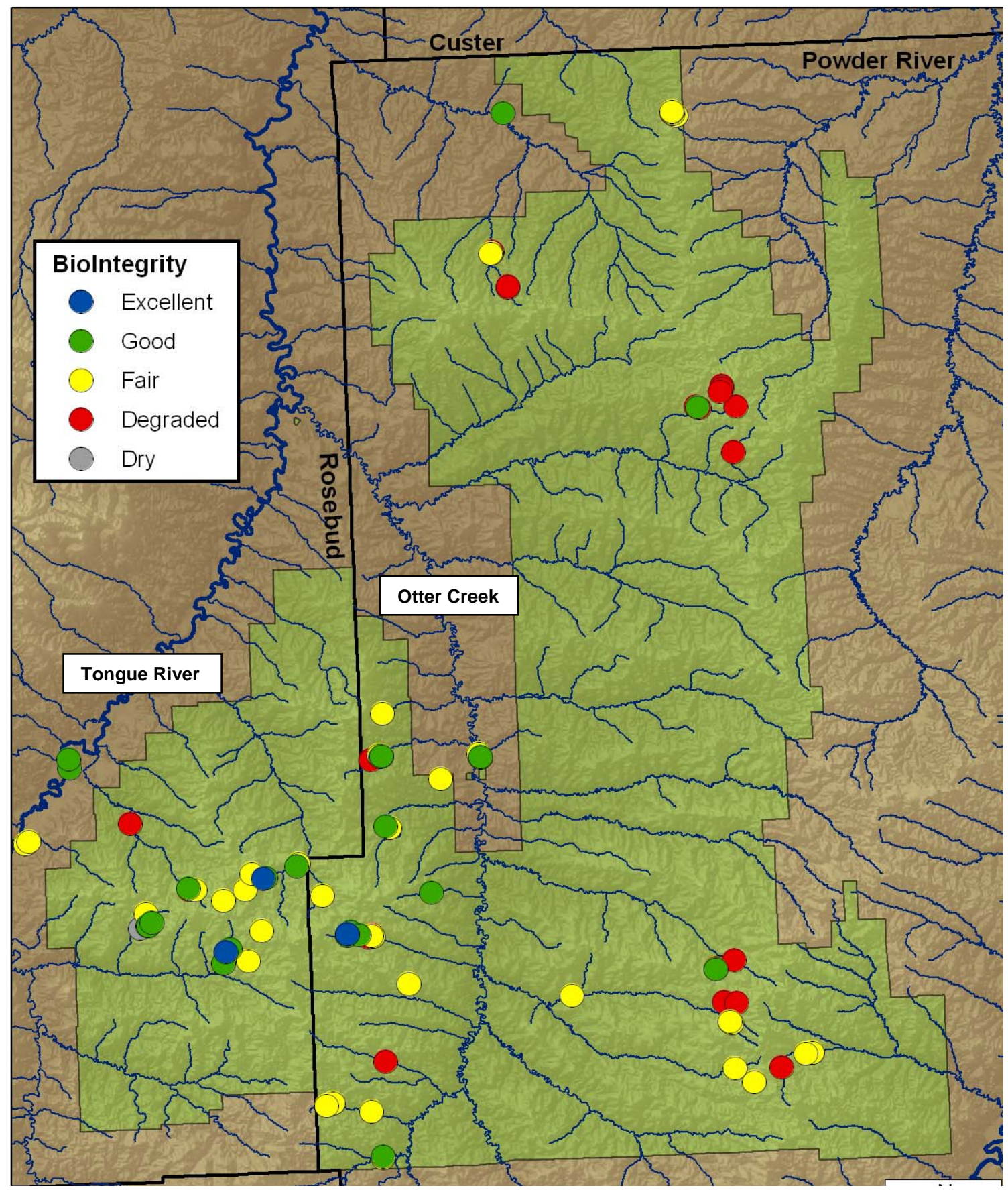


Figure 2. Macroinvertebrate sites sampled in 2004

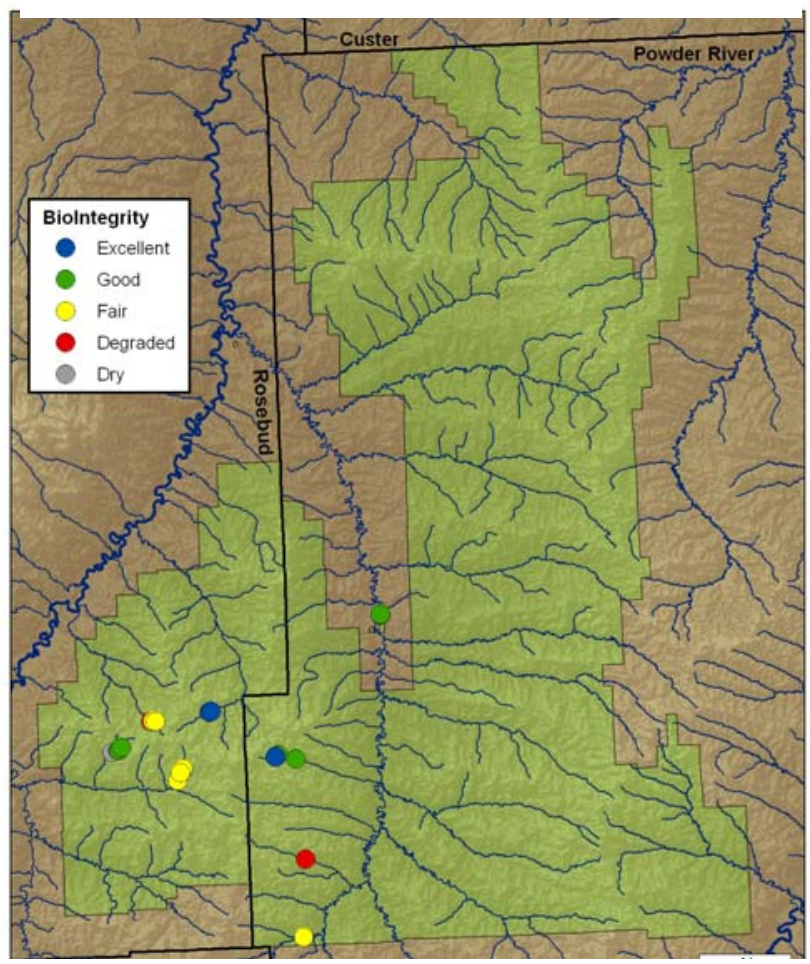

Figure 4a. Macroinvertebrate sites sampled in 2006

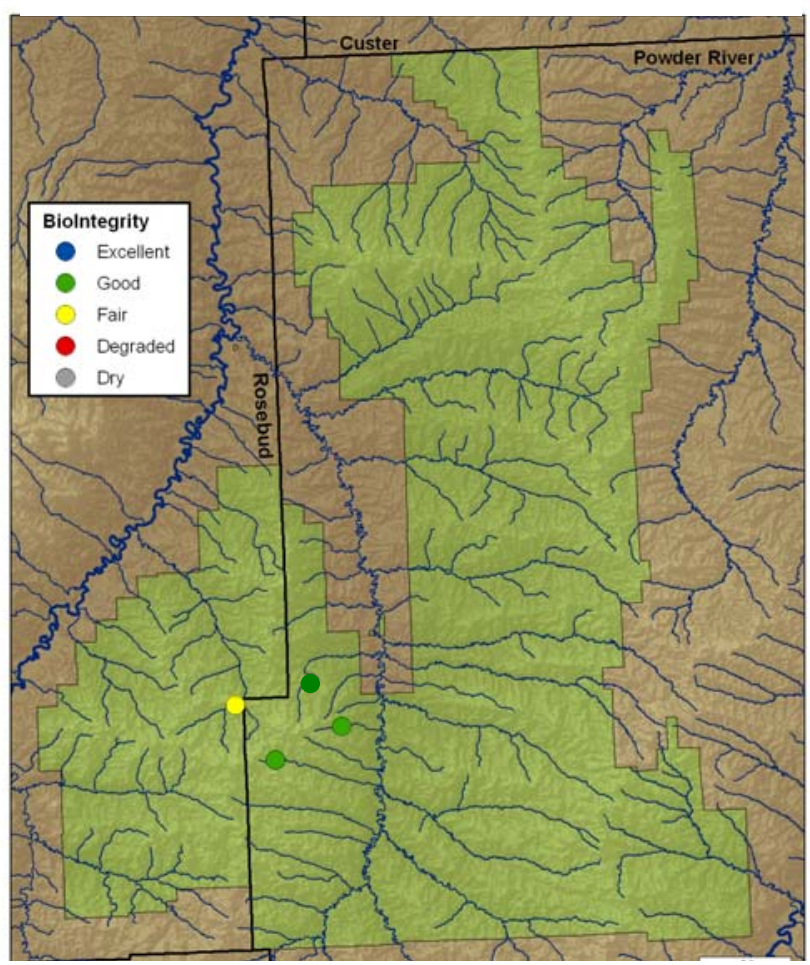

Figure 3. Macroinvertebrate sites sampled in 2005

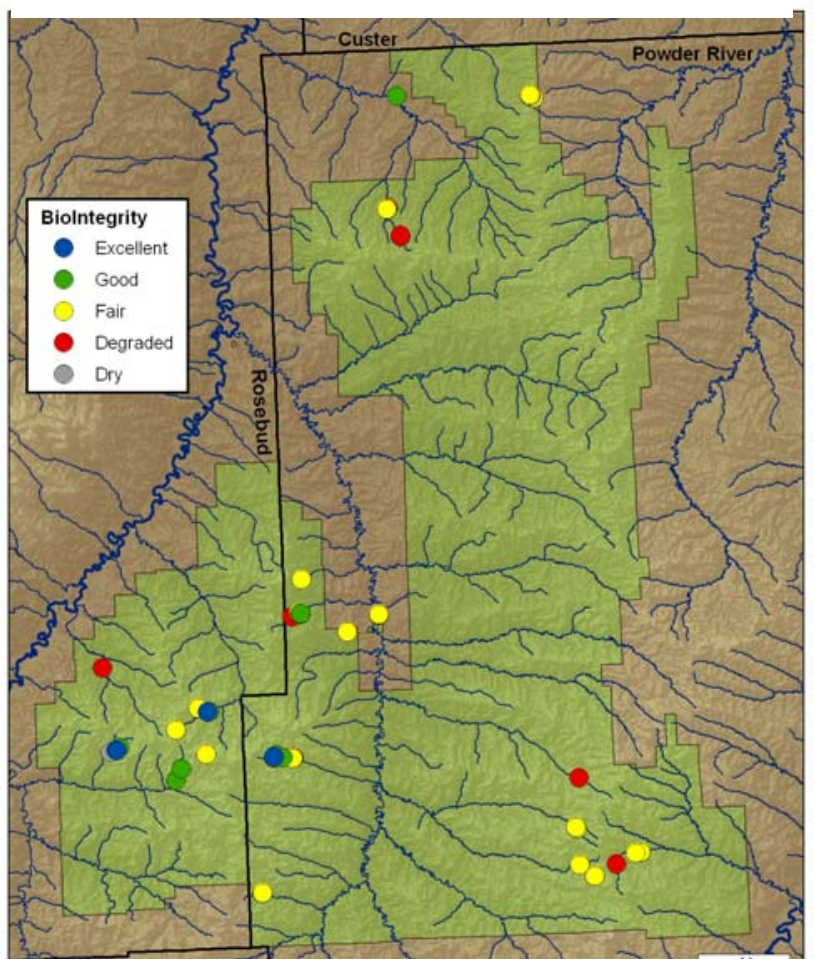

Figure 4b. Macroinvertebrate sites sampled in 2008

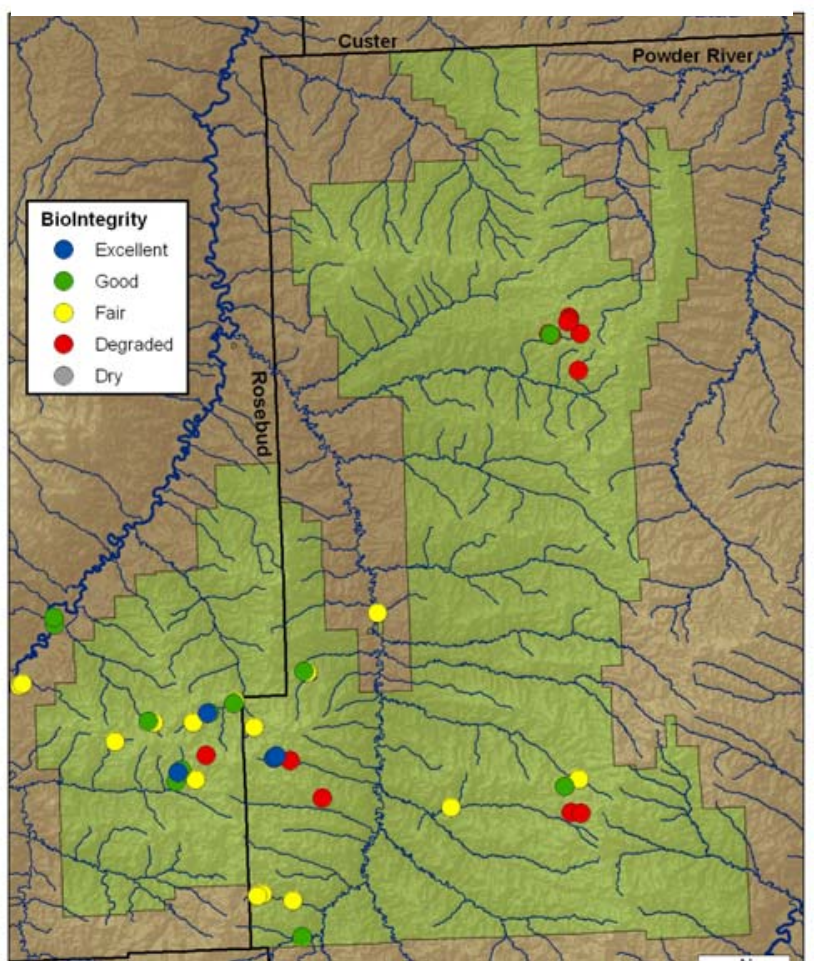




\section{METHODS}

Habitat Evaluation. The evaluation of habitat quality is critical to the assessment of ecological integrity; biological diversity and stream habitat integrity have been shown to be closely linked (Raven 1998). Physical habitat characterization was accomplished with BLM's Habitat Quality Index (HQI) Assessment Data Sheet (Vinson and Hawkins, website, 2002) and EPA's Rapid Habitat Assessment Form (Barbour et al. 1999). Explanations of the habitat assessment methods used on the forest have been addressed previously (Stagliano 2004, Stagliano et al. 2006).

Aquatic Macroinvertebrate Sampling Methods. Benthic macroinvertebrate samples were intensively collected from lotic systems in targeted riffle habitats (cobble/pebble substrates) using a WildcoDipnet ${ }^{\mathrm{TM}}$ with 500-micron mesh following modified EMAP protocols (BLM Buglab website 2002). If shallow riffle areas were not present, EMAP's reach-wide protocol (Lazorchak et al. 2002) was used to sample aquatic invertebrates from all substrates and microhabitats within the reach. For lentic sites and large pools within stream systems, a multihabitat dipnet sample was taken with 20 ( $1 \frac{1}{2}$ meter) jabs along evenly spaced transects in proportion to the habitat types with a 500 micon mesh, long-handled dip net (following Barbour et al. 1999). Sample processing and macroinvertebrate identification procedures were detailed previously (Stagliano et al. 2006). The use of dragonfly metrics has been proposed in wetland assessments based on increased species richness with aquatic habitat complexity. Therefore, in addition to the larvae, we identified adult dragonflies and damselflies opportunistically during the surveys.

\section{Aquatic Macroinvertebrate Metrics}

The Montana DEQ Plains Multimetric Index (MMI) (Bukantis 1998, see Table 1) was previously used for analysis of Custer Forest lotic macroinvertebrate biointegrity, and we will continue to run this MMI in addition to the new 2006 DEQ Plains MMI (Feldman 2006, Table 2) for comparison. Metrics within these MMIs include: total aquatic invertebrate taxa richness (Taxa Richness) and EPT Richness (number of Ephemeroptera, Plecoptera and Trichoptera taxa). The Montana Invertebrate Biotic Index (MTIBI) was also calculated from each sample. The MTBI calculation involves the use of tolerance values of the organisms (ranked 0-10, based on Bukantis 1998 and Barbour et al. 1999). Invertebrates intolerant or sensitive to disturbances are ranked low (0-3), while those very tolerant to degraded conditions are ranked higher (7-10). The 
calculation of the MTBI involves multiplying the number of individuals of taxa (i) found in a sample $\left(\mathrm{n}^{\mathrm{i}}\right)$ by that taxa's tolerance value $\left(\mathrm{TV}^{\mathrm{i}}\right)$ and summing all $\mathrm{n}^{\mathrm{i}} \mathrm{TV}^{\mathrm{i}}$ in the sample. Finally, the $\Sigma \mathrm{n}^{\mathrm{i}} \mathrm{TV}^{\mathrm{i}}$ is divided by the total number of individuals in the sample (TN) to derive the MTBI for the sample. The MTBI was found to be the most responsive macroinvertebrate metric to habitat degradation and cattle usage, significantly correlating with 11 of the analyzed parameters, including the Livestock Use Index (LUI) (Stagliano et al. 2006). The other significant associations with the LUI are percent instream sediments and percent bare ground in the reach, which are typical consequences of cattle trampling in the riparian area. Other metrics and metric scoring are included in Table 1a. Metric scores are added for the eight macroinvertebrate metrics to obtain a final metric score, and this is compared to a known reference stream: the best possible score is 24 . The percentage of the observed score to the best possible score can be used for the assignment of impairment classification (see Table 1b).

Table 1a. Metrics used as biocriteria and scoring criteria to determine impairment for the MT Plains ecoregions (Bukantis 1998).

\begin{tabular}{|l|c|c|c|c|}
\hline \multicolumn{1}{|c|}{ Metrics } & \multicolumn{4}{c|}{ Scores } \\
\hline & 3 & 2 & 1 & $\mathbf{0}$ \\
\hline TAXA RICHNESS & $>24$ & $24-18$ & $18-12$ & $<12$ \\
\hline EPT RICHNESS & $>8$ & $8-6$ & $5-3$ & $<3$ \\
\hline MT BIOTIC INDEX & $<5$ & $5-6$ & $6-7$ & $>7$ \\
\hline \% Dominant Taxa & $<30$ & $30-45$ & $45-60$ & $>95$ \\
\hline \% Collecters & $<60$ & $60-80$ & $80-95$ & $>95$ \\
\hline \%EPT & $>50$ & $50-30$ & $30-10$ & $<10$ \\
\hline \% Scapers + Shredders & $>30$ & $30-15$ & $15-3$ & $<3$ \\
\hline \# Predator taxa & $>5$ & $4-5$ & $3-4$ & $<3$ \\
\hline
\end{tabular}

Table 1b. Assignment of impairment classifications

\begin{tabular}{|c|c|}
\hline $\begin{array}{c}\text { \% Comparibility to } \\
\text { reference or BPS* }\end{array}$ & Classification \\
\hline$>75 \%$ & Nonimpaired (NON) \\
\hline $54-74 \%$ & Slightly impaired (SLI) \\
\hline $21-54 \%$ & Moderately impaired (MOD) \\
\hline$<20 \%$ & Severely impaired (SEV) \\
\hline
\end{tabular}

*BPS-Best Possible Score
Table 2. Impairment determinations from the MT DEQ MMI and O/E (Jessup 2005, Feldman 2006).

\begin{tabular}{l|l|l|l} 
Ecoregion & RlYPACS & MMI & Impairment Determination \\
\hline Mountain & $\geq 0.8$ or $\leq 1.2$ & $\geq 63$ & Not impaired \\
& $<0.8$ or $>1.2$ & $<63$ & Impaired \\
Low Valley & $\geq 0.8$ or $\leq 1.2$ & $\geq 48$ & Not impaired \\
& $<0.8$ or $>1.2$ & $<48$ & Impaired \\
Eastem Plains & $\geq 0.8$ or $\leq 1.2$ & $\geq 37$ & Not impaired \\
& $<0.8$ or $>1.2$ & $<37$ & Impaired
\end{tabular}

We can see that taxa richness measures such as EPT, number of Predator taxa, and percent EPT are expected to decrease with increased impairment, while the MTBI, percent Collectors, and 
percent Dominant taxa will increase.

\section{AQUATIC COMMUNITY RESULTS \& DISCUSSION}

Habitat Evaluations. Overall, three of the 78 visited aquatic sites had no current impairment stressors because they were fenced from cattle. A number of lotic sites (11) were slightly impaired by grazing, but retained good riparian habitat quality or Proper Functioning Condition (PFC) ranked by at least one of the habitat assessment methods. Thirty-five of the sites (54\%) were ranked as moderately impaired or Functional At Risk (FAR), and 29 sites (37\%) had virtually non-functioning riparian areas and heavily impacted instream habitat (Figure 1). Riparian habitat quality measured by the BLM HQI varied from a low score of 6 in a heavily cow-impacted stream reach (Wilbur Creek Spring) to a perfect 24 at the Cow Creek Upper site (cover photo). The average BLM HQI score for 52 stream sites was 17.2, which indicates that most sites have slight to moderate degradation of the riparian condition. These were usually by cattle intrusions and trampling along the stream, which led to bank instability and failure, increased stream wetted width, pocking and sedimentation.

The expected composition of stream benthic substrates in this ecoregion (i.e. Cow Creek, Parrish, and Prune Spring) contains a mix of shale cobbles, pebble and gravel, with fines

accumulating in depositional areas. Sites that had moderate to severe riparian impairment (Ash Creek, Cub Creek, Liscom Butte, Frary, Tooley, Wilbur Creek spring, etc.) had predominately silted substrates, but cobble and gravels are present underneath the deep depositional silt layer; these sites may improve if cattle exclusion occurs, but without a spring flushing flow, silt and anoxic benthic conditions may persist long after exclusion occurs.

Table 3. Reference NWGP Spring indicator species taxa list. Frequency of Occurrence (F of O) and the Indicator Species Analysis (ISA) significance level $(++=<0.01,+=<0.05)$

\begin{tabular}{|c|c|c|}
\hline S005 Indicator Taxon & F of $\mathbf{O}$ & $\begin{array}{l}\text { Sig. } \\
\text { Level }\end{array}$ \\
\hline \multicolumn{3}{|l|}{ Stoneflies } \\
\hline Amphinemura cf. banksi & 0.75 & ++ \\
\hline \multicolumn{3}{|l|}{ Mayfly } \\
\hline Baetis tricaudatus & 1.0 & ++ \\
\hline \multicolumn{3}{|l|}{ Caddisflies } \\
\hline Hesperophylax cf. designatus & 1.0 & ++ \\
\hline \multicolumn{3}{|l|}{ Damselfly } \\
\hline Argia & 1.0 & + \\
\hline \multicolumn{3}{|l|}{ Beetles } \\
\hline Optioservus & 0.75 & ++ \\
\hline Hydroporus & 0.75 & + \\
\hline Oreodytes & 0.75 & + \\
\hline \multicolumn{3}{|l|}{ Diptera (True Flies) } \\
\hline Caloparyphus & 0.75 & ++ \\
\hline Dicranota & 0.75 & + \\
\hline Dixa & 0.75 & + \\
\hline Heleniella & 0.75 & ++ \\
\hline Odontomesa & 0.75 & ++ \\
\hline Ormosia & 0.5 & + \\
\hline Pedicia & 0.5 & + \\
\hline Pseudodiamesa & 0.75 & + \\
\hline Radotanypus & 0.75 & ++ \\
\hline Tipula & 1.0 & ++ \\
\hline
\end{tabular}


Fish Communities. Otter Creek at the CCC Camp and Beaver Creek at the state section were the only "connected” lotic sites visited that had visible fish populations. Beaver Creek had a lake chub (Couesius plumbeus) population of $\sim 70$ individuals of various size classes in two large pools (15-20m long) within the reach. Numerous minnows were seen while sampling Otter Creek, but only a fathead minnow (Pimephales promelas) was collected during dipnet sampling. Isolated spring-upwelling pools of Taylor Creek (Stagliano 2004) and Horse Creek (Watschke, pers. comm. 2009) contain remnant, but reproducing populations of lake chubs. These are truly unique occurrences within the Ashland District representing a multi-decadal event of colonization during a wetter climate and then an isolation event during dryer climates. Black bullheads were identified swimming in Poker Jim Reservoir, but none were collected. Further investigation into the fish species distribution in the Ashland District was not the scope of this project.

Macroinvertebrate Community Diversity: Overall, 132 macroinvertebrate taxa (eleven EPT taxa) were collected from all sites and years 2004-2008, but no USFS species of concern (SOC)
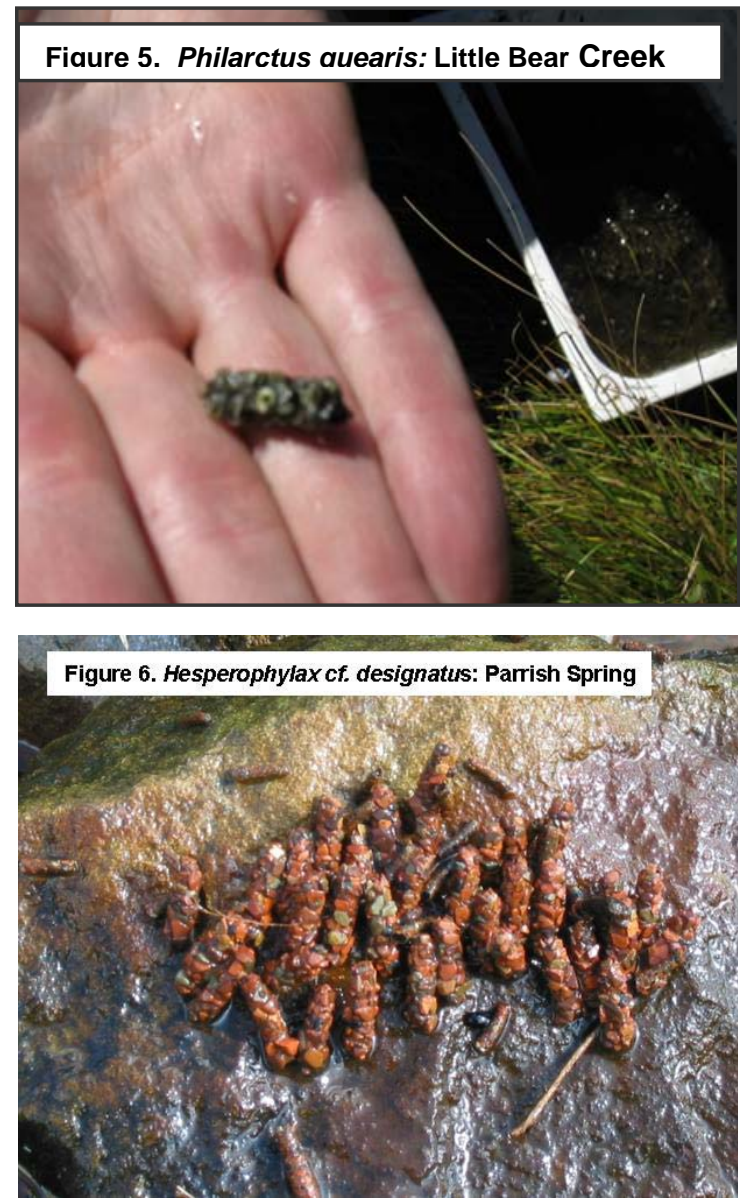

or species of interest (SOI) were discovered. At this level of taxonomic resolution, we seemed to have reached a "plateau" of aquatic taxa richness. Twelve sites in 2004 and fourteen from 2005, yielded 118 and 111 taxa, respectively, but we have only accumulated $\sim 20$ more taxa with the addition of $\sim 50$ sites. Additional species level taxonomic work would likely add 50-100 aquatic species to this list, but would require costly adult insect collections and identification. A unique caddisfly, Philarctus quaeris that produces its case from snail shells was found in the Little Bear Creek pools in 2008, but not from the 2004 sample; this permanent pool site maintains a high diversity of macroinvertebrates (32 taxa), including five snail species and nine aquatic beetle taxa. (Figure 5). The only stonefly taxa 
(Amphinemura cf. banksi) reported in the Ashland District was found at the three reference condition spring systems. Amphinemura can persist in springs and intermittent streams through a long egg-diapause period during the summer months, and perform much of their growth in the fall and winter months emerging in May (Stewart and Stark 1993). The S005 reference condition indicator mayfly, Baetis tricaudatus was found at seven of the higher integrity spring sites, and in Otter Creek 2004, but not in 2005. Three mayflies, Callibaetis ferrugineus, C. fluctuans and Caenis latipennis were the most ubiquitously distributed of EPT taxa across the Ashland District, occurring at nine, eleven and 12 sites respectively; these species occupied stock

Figure 7. Sites with NWGP Spring S005 Indicator Taxa.

$$
\text { Excellent }=>11 \text { species, Good 9-11, Fair 5-8, Degraded }=<5
$$

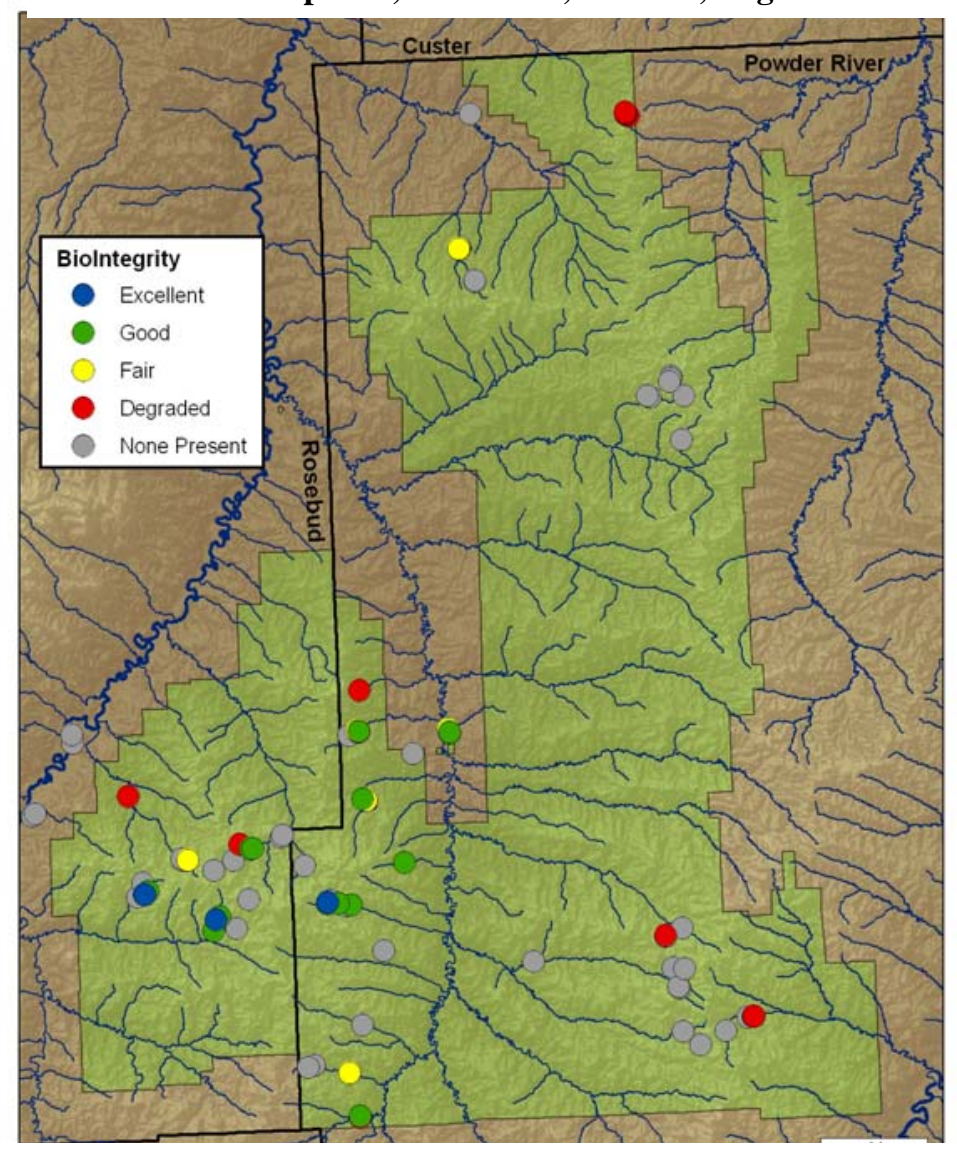

pond habitats and pool areas of streams with aquatic vegetation. The caddisfly, Hesperophylax $c f$. designatus (Figure 6), a Reference Spring Indicator Taxon (Table 4) was found at eleven springs and streams with at least some clean gravel substrate and large cobbles or woody debris present (Figure 7). Sites containing the most high-integrity spring indicator taxa were predominately in the southwestern part of the Ashland District where shale and sandstone is more prevalent (Figure 7). The maximum number of EPT taxa present in excellent condition springs was four: the stonefly (Amphinemura banksi),

mayfly (Baetis tricaudatus) and two caddisflies. An interesting taxon reported from the 2005 Charcoal Creek site, was the Dryopid riffle beetle, Helichus $c f$. lithophilus, which has not been collected at any other spring site, while two other riffle beetles, Optioservus seriatus \& $O$. quadrimaculatus have been reported from nine spring sites, all with high habitat integrity. Average macroinvertebrate taxa richness per lotic and lentic sites was 20 and 16, respectively, and the highest taxa richness reported was 53 at the Otter Creek 2004 site and two spring sites with 38 taxa. While there is no current standardized method for analyzing lentic 
macroinvertebrates, Cow Creek Reservoir, Mud Turtle Reservoir, and Poker Jim Pond contain highly diverse lentic macroinvertebrate communities, including five dragonfly and five damselfly species. The damselfly species found in the high-quality springs of the Ashland District is likely Argia vivida, based on an adult identification. Cow Creek Reservoir also remains the hotspot for herpetofauna with five species reported.

Macroinvertebrate Community Metrics. Using MT DEQ’s macroinvertebrate multimetric index (MMI) combined with the Spring Indicator (O/E), four of the 52 lotic sites were ranked non-impaired (excellent biological integrity), 12 were slightly-impaired, 24 moderately-impaired and 12 severely degraded (Appendix A). Cow Creek above reservoir, Parrish Spring, Prune (Charcoal) Creek Spring and Stocker Branch contain reference condition lotic spring macroinvertebrate communities. In terms of multi-metric macroinvertebrate indices (MMI analysis), 26 sites were analyzed with the $1998 \mathrm{MMI}$, and most of the 2006 and 2008 sites were evaluated with the 2006 DEQ MMI or the O/E model. Cow Creek upper and Stocker Branch are reference condition sites with excellent biointegrity, while Charcoal Creek, Cow Creek lower and Brian Spring \#1 were classified as non-impaired, but not in the reference condition classification. The reason Brian Spring \#1 made this category was the presence of the caddisfly, Limnephilus comprising a large percentage of the EPT organisms in the sample, which artificially boosted the percent EPT measure. Slightly-impaired (good integrity) macroinvertebrate communities included Brian Spring \#2, Little Bear Creek spring, Otter Creek, Beaver Creek, Paget Creek spring and Stag Rock Spring, in order of decreasing index scores (Figure 1, Appendix A).

Macroinvertebrate Lotic Site Revisits. Three sites sampled in 2004 and again in 2005 showed improved macroinvertebrate taxa metrics, while Otter Creek’s macroinvertebrate communtiy seems to have decreased in biointegrity (Figure 8). Charcoal Creek 2005 was further upstream from the 2004 site and the BLM HQI improved compared to the 2004 reach. Accordingly 14 additional taxa were reported, and the new site's macroinvertebrate community ranked non-impaired compared to the previous years slightly-impaired MMI rank. The other 3 sites were sampled in the exact same reach, yet still produced different macroinvertebrate taxa results (Figure 8). Cow Creek upper remained unimpaired, had similar MTBI scores, but gained 12 taxa from 2004. Cow Creek lower reported 11 additional taxa in 2005 and greatly improved the MTBI score from 6.37 to 4.59, therefore 
improving biointegrtiy to the low end of unimpaired (Figure 8, Table 6). Otter Creek reported 15 fewer taxa and declined in integrity with the MMI score (18 to15) causing a shift to slightly-impaired (Figure 8).

Figure 8. Site Revisits during the 2004-2008 study. MMI Score is the DEQ 1998 model.

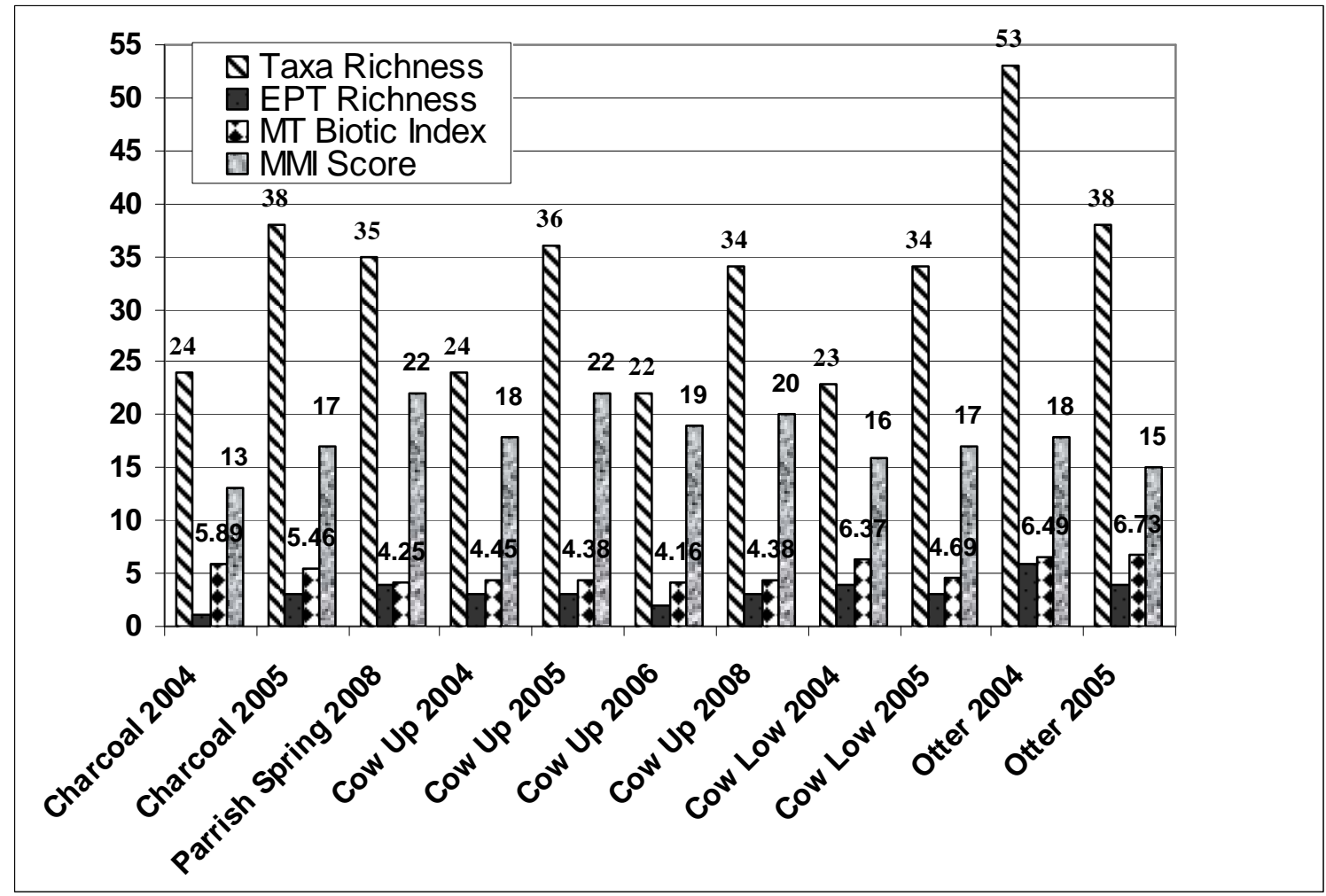

These temporal community changes are found in examining only two years of data. The stream reaches considered for reference sites in a biomonitoring program should be sampled annually to encompass all possible within-site variability, as they are compared to newly sampled sites elsewhere in the watershed. A new site sampled in 2008, Parrish Spring compares very favorably to the other reference macroinvertebrate sites in the Ashland and will also be considered a high biointegrity S005 spring (Table 4, Figure 9). The DEQ 2006 Plains MMI seemed upresponsive to changes in the Cow Creek macroinvertebrate communities and ranks all sites as unimpaired (>37), upstream and downstream of the reservoir despite obvious silt and instream degradation downstream of the reservior and identified by the other metrics (Table 4, Figure 9). The DEQ LowVal MMI is designed to be used in the valleys of the Middle Rockies Ecoregion and therefore is inapplicable here, but I ran the samples to evaluate the response, and this Index seemed to track the community changes better than the Plains MMI (Table 4). We believe the 1998 DEQ MMI and S005 Spring O/E better reflect the "true conditions" on the ground and within the 
macroinvertebrate communities responding to in-stream and/or riparian conditions (Table 6). The MTBI also tracks habitat conditions better than the 2006 MMI with scores less than 4.5 unimpaired and those $>4.5$ slightly impaired and scores $>6.0$ moderately to severely impaired (Table 4).

Table 4. Reference site macroinvertebrate metric comparisons from 2004 to 2008.

Bold/underlined values are below the impairment threshold for integrity measure (see Table 3)

\begin{tabular}{lccccc|cc|}
\hline \multicolumn{1}{c}{ WaterbodyName: } & Coll_Date & Total_Ind & $\begin{array}{c}\text { DEQ } \\
\text { Plains } \\
\text { Index }\end{array}$ & $\begin{array}{c}\text { DEQ } \\
\text { LowVal } \\
\text { Index }\end{array}$ & MTIBI & $\begin{array}{c}\text { DEQ } \\
\mathbf{1 9 9 8} \\
\text { MMI }\end{array}$ & O/E \\
\hline Parrish Spring & 13-May-08 & 488 & 63.96 & 49.84 & 4.25 & 22 & 0.93 \\
Cow Creek above Res t1 & 20-May-04 & 491 & 46.02 & $\underline{\mathbf{3 1 . 7 5}}$ & 4.45 & 18 & 0.79 \\
Cow Creek above Res t2 & 20-May-05 & 569 & 67.70 & $\underline{\mathbf{4 4 . 4 5}}$ & 4.38 & 22 & 1.00 \\
Cow Creek above Res t3 & 19-May-06 & 319 & 76.19 & 67.76 & 4.16 & 19 & 0.86 \\
Cow Creek above Res t4 & 12-May-08 & 600 & 64.51 & $\underline{\mathbf{4 0 . 0 7}}$ & 4.38 & 20 & 0.93 \\
Cow Creek below Res t1 & 20-May-04 & 340 & 54.03 & $\underline{\mathbf{3 5 . 1 7}}$ & $\underline{\mathbf{6 . 3 7}}$ & $\underline{\mathbf{1 6}}$ & $\underline{\mathbf{0 . 3 6}}$ \\
Cow Creek below Res t2 & 20-May-05 & 594 & 64.38 & 63.01 & $\underline{\mathbf{4 . 6 9}}$ & $\underline{\mathbf{1 7}}$ & $\underline{\mathbf{0 . 4 3}}$ \\
\hline
\end{tabular}

Figure 9. DEQ MMI Scores converted to \% of reference or best possible score for 2006 MMI (top) and the 1998 model (bottom). Threshold line is $75 \%$.

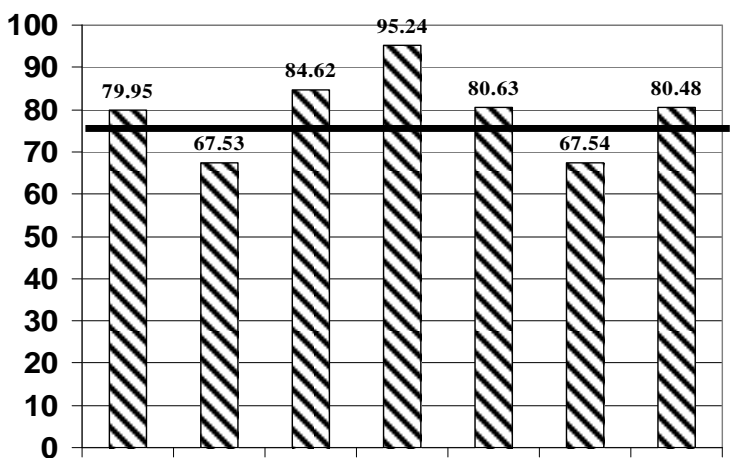

\% of Reference Score 1998 MMI Score

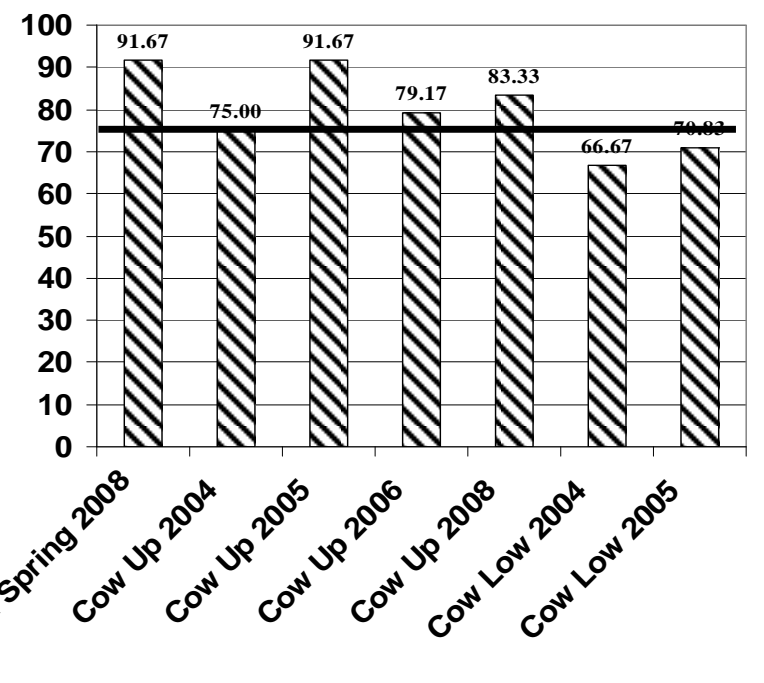

We converted the raw DEQ MMI Score to a percent of best possible score to evaluate metric performance (Figure 9). The 2006 DEQ MMI would rank the reference 2004 Cow Creek reach impaired (below the 75\% threshold) and the impaired 2005 Cow Creek below reservior reach as unimpaired, whereas the 1998 DEQ MMI ranks the sites in line with the Spring Indicator O/E (Table 6). Cow Creek sites below the reservior are missing enough of the spring reference taxa to trigger the $\mathrm{O} / \mathrm{E}$ to rank them as impaired, while the 2006 DEQ MMI is not sensitive enough to these specific taxa, and are only considering total taxa and EPT taxa, although a few of these taxa replacements are far more tolerant to impairment the the spring indicator taxa. 


\section{Site Descriptions}

Cow Creek below the Reservoir- Fraxinus

pennsylvanica/Prunus virginiana riparian community as well as a Carex nebrascensis (grazing dis-climax type) (Photo at right looking downstream). This site has ecological potential to recover if cattle exclusion occurs. Many of the reference indicator macroinvertebrate taxa consistent with upstream Cow Creek are present in low numbers, but so are many tolerant taxa in the cattle-hummocked areas.

\section{Cow Creek below the Reservoir (New Beaver Ponded}

Areas)-(Photo looking upstream). This site had a high \% of recent macroinvertebrate colonizers (Corixids, backswimmer waterbugs: Notonecta, Aedes sp. mosquito larvae and the pioneering Hydrophilidae and Dytiscidae beetles: Hydroporus, Berosus, Oreodytes) and thus, did not score well with the metrics, as many of these are tolerant taxa also found in the cattle-hummocked areas. The ecological potential of this site as an amphibian breeding area is great, but not advantageous for lotic macroinvertebrate communities as it transitions to a lentic ponded site.

\section{Parrish Spring trib to Poker Jim Reservoir}

Single thread channel in with good habitat integrity, mostly clean gravel/cobble substrate and a high proportion of the Spring Reference Condition Indicator species present, reference class integrity. No amphibians or reptiles were reported here or in any other single thread, non cattlehummocked stream

\section{Stocker Branch Beaver Introduction Area - A}

macroinvertebrate sample taken here in 2008 contained a fairly depauperate macroinvertebrate community (12 taxa). The macroinvertebrate community is typical of newly colonized stock ponds, as well as some sharing taxa of perennial spring sites that are slightly impaired and able to tolerate warmer, stagnant water. No herpetofauna were detected in the vicinity of the site during this visit, although bullfrogs have been reported in a stock pond $\sim 1 \mathrm{~km}$ down drainage.
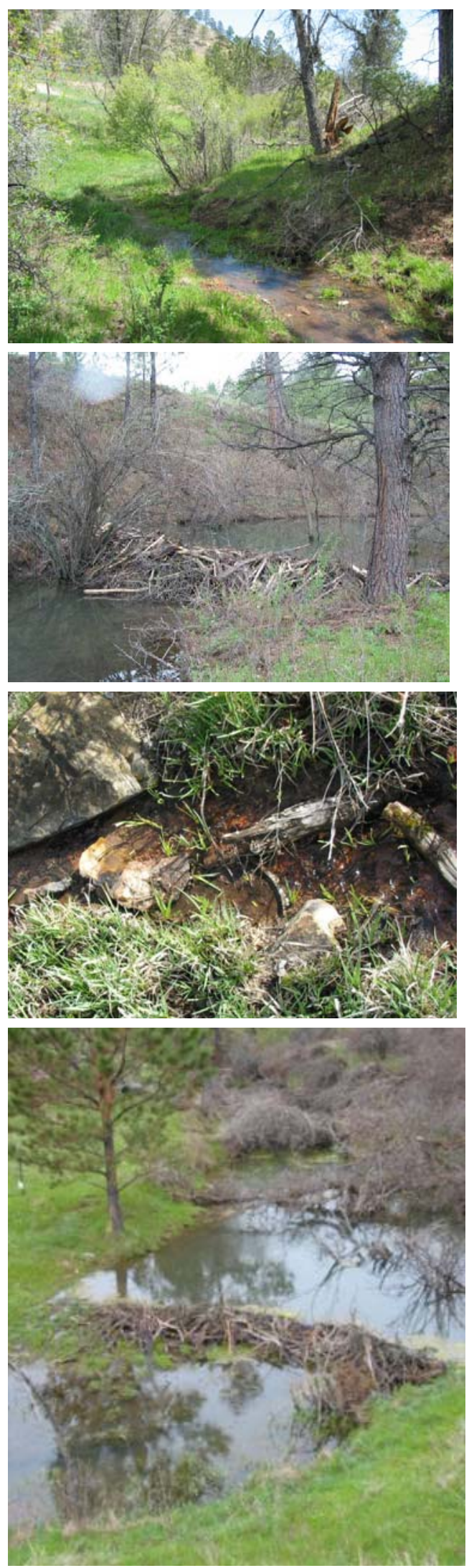


\section{CONCLUSIONS AND RECOMMENDATIONS}

The NWGP Perennial Spring ecological system (S005) has numerous examples within the Ashland District of the Custer Forest, but unfortunately, the vast majority ( $>90 \%$ ) of these have been impaired through a legacy of human activities (i.e. wells, dams, grazing). We recommend that the few unaltered or restored spring systems under USFS management should be further protected and managed to conserve the unique invertebrate fauna that these systems bring to the aquatic diversity of the forest. These specific reference quality sites include: Cow Creek upper, Parrish Spring, Stocker Branch and Charcoal (Prune Spring) Creek. These sites are recommended candidates for reference stream status against all small spring streams $\left(1^{\text {st }}-2^{\text {nd }}\right.$ order $)$ in the Custer Forest and should be compared with sites where restoration activities occur to document if management actions are improving the ecological integrity of the system. The Spring Indicator O/E and 1998 DEQ MMI far outperformed the new 2006 DEQ MMI Model and are the recommended methods of assessing spring sites on the Ashland District or elsewhere in the Northern Great plains ecoregion. The reference sites were highest in overall macroinvertebrate and plant community and habitat integrity, except for the some cattle usage in the Charcoal Creek and Stocker Branch riparian areas. Revisits to these sites from 2004 to 2005 revealed a fairly consistent macroinvertebrate community that is stable across most water quality macroinvertebrate measures evaluated. These sites are inhabited by macroinvertebrate taxa found nowhere else in the Ashland District of the Custer National Forest. They represent isolated meta-populations that could recolonize other spring sites as restoration projects improve the habitat preferred by these more intolerant taxa. Furthermore, the only SOC plant species surveyed in 2006 were found at these sites. Additional sites that have high ecological potential to recover to a biologically intact condition, if cattle exclusion and stream restoration occur, include Cow Creek below the reservoir, Little Brian Spring \#1, Brian Spring \#2, Ash Creek Spring down, and 2004 sites, Davis Prong, Black Canyon Reservoir Spring and South Fork Poker Jim Creek. Perennial spring stream sites with high riparian habitat quality and macroinvertebrate and plant biodiversity were not conducive to amphibians breeding, or their presence. Only after high-impact livestock use causes increased stream wetted width, more emergent in-stream vegetation and increased sedimentation do amphibians begin to use these spring areas, which naturally have narrow, single-thread channels and cobble substrate (see Appendix C).

Numerous stock ponds and reservoirs (Cow Creek Reservoir for example) provide ample 
aquatic habitat and breeding areas for the propagation and life-cycle completion of the herpetofauna of the Ashland District of the Custer National Forest. Additionally, new beaver-ponded areas (Stocker Branch and Cow Creek below the reservoir) will significantly contribute to amphibian breeding areas and could be managed for cattle watering access. Spring seeps and streams in their natural condition were probably always unattractive breeding areas for amphibians, and thus should be managed for their naturally occurring lotic biota. Unfortunately, these macroinvertebrate species are intolerant to disturbance, and unless effective riparian management is performed (e.g. cattle fencing, bank stabilization and riparian buffer planting), eventually there may be no biologically intact Northwestern Great Plains Perennial Spring Ecosystem type left in the Ashland District. 


\section{Literature Cited}

Allen, J.D., D.L. Erickson and J. Fay. 1997. The influence of catchment land use on stream integrity across multiple spatial scales. Freshwater Biology 37: 149-161.

Barbour, M.T., J. Gerritsen, B.D. Snyder and J.B. Stribling. 1999. Rapid Bioassessment Protocols for Use in Streams and Wadeable Rivers: Periphyton, Benthic Macroinvertebrates and Fish. 2nd edition. EPA 841-B-99-002. U.S. Environmental Protection Agency; Office of Water. Washington, D.C.

Beschta, R.L. and W.S. Platts. 1986. Morphological features of small streams: significance and function. Water Resources Bulletin 22:369-380.

Bukantis, B. 1998. Rapid bioassessment macroinvertebrate protocols: sampling and sample analysis SOP's. Montana Department of Environmental Quality. Helena MT

Erman NA. 2002. Lessons from a long-term study of springs and spring invertebrates (Sierra Nevada, California, USA) and implications for conservation and management. In: Sada DW,Sharpe SE, editors; 2002; Las Vegas, NV.

Feldman, D. 2006. Interpretation of New Macroinvertebrate Models by WQPB. Draft Report. Montana Department of Environmental Quality, Planning Prevention and Assistance Division, Water Quality Planning Bureau, Water Quality Standards Section.1520 E. 6th Avenue, Helena, MT 59620. 14 pp.

Goforth, R.R., D.M. Stagliano, J. Cohen, M. Penskar, Y.M. Lee, J. Cooper. 2002. Biodiversity analysis of selected riparian ecosystems within a fragmented landscape. Michigan Department of Environmental Quality, Office of the Great Lakes. Report \# 2001-06. 148 pages.

Karr J. and E.W. Chu. 1999. Restoring Life in Running Waters: Better Biological Monitoring. Island Press. Washington, D.C.

Lazorchak, J.M., Klemm, D.J., and D.V. Peck (editors). 2002. Environmental Monitoring and Assessment Program - Surface Waters: Field Operations and Methods for Measuring the Ecological Condition of Wadeable Streams. EPA/620/R-94/004F. U.S. Environmental Protection Agency, Washington, D.C.

MTDEQ. 2005. Sample Collection, Sorting, and Taxonomic Identification of Benthic Macroinvertebrates. Montana Department of Environmental Quality Water Quality Planning Bureau Standard Operating Procedure WQPBWQM-009. April 2005.

Myers, M. 1995. Aquatic Insects in the Springs of the Great Basin. Department of Environmental Science, Policy and Management, UC Berkeley.

Myers, M. and V. Resh 2002. Trichoptera and other macroinvertebrates in springs of the Great Basin: Species composition, richness, and distribution. Western N. Am. Nat. Vol. 62, no. 1, pp. 1-13.

Naiman, R. J. and H. Decamps. 1997. The ecology of interfaces: riparian zones. Ann. Rev. Ecol. Systematics 28, 621-658.

Perla, B. and Stevens L.E. 2003. Biodiversity and productivity of an undisturbed spring compared with adjacent grazed riparian and upland habitats. In: Stevens LE, Meretsky VJ, editors. Every last 
drop: Ecology and conservation of springs ecosystems. Flagstaff, AZ: Univ. of Arizona Press.

Raven, P.J. et al 1998. River Habitat Quality: The physical characters of rivers and streams in the UK and Isle of Man. Environmental Agency. ISBN 187376042 9. Bristol, England.

Sada DW, Fleishman E, Murphy DD. 2005. Associations among spring-dependent aquatic assemblages and environmental and land use gradients in a Mojave Desert mountain range. Diversity and Distrubutions 11:91-99.

Stagliano, D. M. 2008. Aquatic Macroinvertebrate Inventory \& Assessment of Springs and Seeps within Bighorn Canyon National Recreation Area (BICA). A report to the Western Parks Association and the National Parks Service 16p plus appendices. http://mtnhp.org/reports/BICASprings.pdf

Stagliano, D.M., S.A.Mincemoyer and B.A. Maxell. 2006. An Integrative Biological Assessment of Sites in the Custer National Forest Ashland Ranger District. A Report to the Custer Forest Ashland District. http://mtnhp.org/Reports/Custer_Forest_Project_2006.pdf

Stagliano, David, M. 2005. Aquatic Community Classification and Ecosystem Diversity in Montana's Missouri River Watershed. Report to the Bureau of Land Management. Montana Natural Heritage Program, Helena, Montana. 65 pp. plus appendices.

Stagliano, D. M. 2004. A Biological Assessment of Sites in the Custer National Forest (Ashland Ranger District) Using Aquatic Macroinvertebrates. Stag Benthics, Helena, Montana. 19 pp. plus appendices.

Stewart, K.W. and B.P. Stark. 1993. Nymphs of North American Stonefly Genera (Plecoptera). University of North Texas Press, Denton, Texas.

United States Environmental Protection Agency (USEPA). 1998. Clean Water Action Plan: Restoring and Protecting America's Waters. USEPA (EPA-840-R-98-001) Washington, D.C. 
Appendix A. Location, year sampled, biointegrity and quality of S005 indicator species for macroinvertebrate sites sampled within the Ashland District Custer Forest. A=excellent, D=degraded

\begin{tabular}{|c|c|c|c|c|c|c|c|c|}
\hline Description & $\underline{\text { Latitude }}$ & $\underline{\text { Longitude }}$ & $\underline{2004}$ & $\underline{2005}$ & $\underline{2006}$ & $\underline{2008}$ & $\underline{\text { Overall }}$ & $\underline{\mathrm{S} 005}$ \\
\hline Ash Cr north $\overline{\mathrm{nr} . \text { Cook Mtn }}$ & $4 \overline{5.660655}$ & $-\overline{106.105216}$ & & $\mathrm{D}$ & & & $\mathrm{D}$ & $E$ \\
\hline Ash Cr north nr. Cook Mtn & 45.679935 & -106.117189 & & C & & & C & $\mathrm{C}$ \\
\hline Ash Spring Main & 45.679952 & -106.117693 & & C & & & C & $\mathrm{C}$ \\
\hline Beaver Creek state section & 45.756660 & -106.103550 & & B & & & B & $E$ \\
\hline Blacks Sawmill Pond & 45.347543 & -106.286742 & & & $\mathrm{C}$ & B & B & $\mathrm{E}$ \\
\hline Blacks Sawmill Pond below & 45.348882 & -106.285233 & & & & $\mathrm{C}$ & C & $E$ \\
\hline Bloom Cr. In the Powder Drainage & 45.233199 & -105.899529 & & C & & & C & $\mathrm{D}$ \\
\hline Brian Spr. North Nr. King Mtn & 45.406520 & -106.219066 & & C & & & C & $\mathrm{D}$ \\
\hline Brian Spr.North Nr. King Mtn & 45.406547 & -106.218589 & & D & & & D & $\mathrm{D}$ \\
\hline Brian Spr.South Nr. King Mtn & 45.405798 & -106.218637 & & B & & & B & $\mathrm{D}$ \\
\hline Brian Spr.South Nr. King Mtn & 45.406311 & -106.218395 & & C & & & C & $\mathrm{D}$ \\
\hline Brian Spring \# 2 & 45.406094 & -106.218378 & & B & & & B & B \\
\hline Charcoal Creek abv res. & 45.317911 & -106.402658 & B & A & & & B & A \\
\hline Charcoal Creek abv res. 2 & 45.318059 & -106.402041 & B & A & & & B & A \\
\hline Charcoal Prune Spring & 45.319837 & -106.399196 & B & B & & & B & B \\
\hline Charcoal Reservoir & 45.317060 & -106.408480 & $E$ & $E$ & & & $E$ & $E$ \\
\hline Chromo Spring, 1.1 miles WSW of Ch & 45.429750 & -106.216080 & & $\mathrm{C}$ & & & $\mathrm{C}$ & $\mathrm{D}$ \\
\hline Cow Creek & 45.307131 & -106.234462 & & & & $\mathrm{D}$ & $\mathrm{D}$ & $E$ \\
\hline Cow Creek above reservoir & 45.309066 & -106.249827 & $A$ & A & B & $A$ & $A$ & A \\
\hline Cow Creek above reservoir & 45.309079 & -106.249839 & $A$ & $A$ & $\mathrm{~B}$ & $A$ & $A$ & A \\
\hline Cow Creek below reservoir & 45.307470 & -106.230170 & B & & & & C & B \\
\hline Cow Creek below reservoir & 45.307730 & -106.231400 & & C & & & $\mathrm{C}$ & $\mathrm{C}$ \\
\hline Cow Creek Bog, 0.77 miles ESE of $C_{1}$ & 45.308049 & -106.230963 & & $\mathrm{D}$ & & & $\mathrm{D}$ & $E$ \\
\hline Cow Creek Reservoir & 45.310392 & -106.247343 & B & B & & A & B & $E$ \\
\hline Cow Creek Spring & 45.308347 & -106.249952 & & B & & & $\mathrm{B}$ & B \\
\hline Cub Creek Spring & 45.238449 & -106.224792 & D & & & & $\mathrm{D}$ & $E$ \\
\hline Cy Spring & 45.280320 & -106.204800 & & & & $\mathrm{D}$ & C & $E$ \\
\hline Davis Prong Hanging Woman & 45.295666 & -106.345527 & C & B & & $\mathrm{B}$ & B & B \\
\hline Drop Tube Reservoir & 45.392260 & -106.173580 & & C & & & $\mathrm{C}$ & $E$ \\
\hline East Spring below Wilbur Creek Res. & 45.590050 & -105.934190 & & & & $\mathrm{D}$ & $\mathrm{D}$ & $E$ \\
\hline Experimental Pasture Reservoir & 45.312830 & -106.315630 & & $\mathrm{C}$ & & D & C & $E$ \\
\hline Fairy Shrimp Pools near Antelope Cr€ & 45.218251 & -105.944184 & & $\mathrm{C}$ & & & $\mathrm{C}$ & $E$ \\
\hline Fly Creek Reservoir & 45.564790 & -105.937800 & & & & $\mathrm{D}$ & $\mathrm{D}$ & $E$ \\
\hline Fray Pond & 45.590444 & -105.963960 & & & & B & $\mathrm{B}$ & $E$ \\
\hline Fray Spring & 45.590030 & -105.962610 & & & & $\mathrm{D}$ & $\mathrm{D}$ & $E$ \\
\hline Hansen Reservoir & 45.336720 & -106.367780 & C & & & & $\mathrm{C}$ & $E$ \\
\hline Hansen Spring & 45.601530 & -105.944260 & & & & $\mathrm{D}$ & $\mathrm{D}$ & $E$ \\
\hline Hansen Spring South & 45.600430 & -105.944660 & & & & $\mathrm{D}$ & $\mathrm{D}$ & $E$ \\
\hline Hazel Creek Reservoir & 45.225877 & -105.922728 & & $\mathrm{D}$ & & & $\mathrm{D}$ & $E$ \\
\hline Liscom Mountain Spring, 0.6 miles NN & 45.751454 & -105.970064 & & $\mathrm{C}$ & & & C & $\mathrm{D}$ \\
\hline Liscom Mtn Spring above rd & 45.752082 & -105.972766 & & $\mathrm{C}$ & & & C & $\mathrm{D}$ \\
\hline Liscom Mtn Spring below rd & 45.753133 & -105.973243 & & C & & & $\mathrm{C}$ & $\mathrm{D}$ \\
\hline Little Bear Creek & 45.185591 & -106.230022 & $\mathrm{C}$ & & & $\mathrm{C}$ & $\mathrm{C}$ & $\mathrm{D}$ \\
\hline Little Bear Creek spring & 45.186390 & -106.230027 & & & & B & B & B \\
\hline Little Brian Spring & 45.406730 & -106.220385 & & $\mathrm{C}$ & & & $\mathrm{C}$ & C \\
\hline Mud Turtle Reservoir & 45.281280 & -105.969480 & & & & B & B & $E$ \\
\hline Mud Turtle Spring & 45.281920 & -105.969510 & & & & C & $\mathrm{D}$ & $\mathrm{D}$ \\
\hline O'Dell Creek Spring & 45.330964 & -106.267876 & & & & $\mathrm{C}$ & $\mathrm{C}$ & $\mathrm{E}$ \\
\hline O'Dell Reservoir & 45.330590 & -106.343830 & & C & & & $\mathrm{C}$ & $E$ \\
\hline Otter Creek @ old CCC camp & 45.402940 & -106.142320 & B & $\mathrm{C}$ & & & B & B \\
\hline Otter Creek, 5.9 miles N of Stag Rock & 45.405345 & -106.143620 & & & & C & C & C \\
\hline Paget Creek & 45.367560 & -106.217330 & & & & B & B & B \\
\hline Paget Creek spring & 45.366530 & -106.214230 & & & & $\mathrm{C}$ & $\mathrm{C}$ & $\mathrm{C}$ \\
\hline Parrish Spring & 45.301841 & -106.343440 & & & & A & A & A \\
\hline Phillips Butte Reservoir & 45.263240 & -105.964570 & & & & $\mathrm{D}$ & $\mathrm{D}$ & $E$ \\
\hline Pierce Reservoir & 45.285650 & -105.955060 & & $\mathrm{D}$ & & C & $\mathrm{D}$ & $E$ \\
\hline Poker Jim Pond Beaver Pools & 45.300639 & -106.343037 & & & & $\mathrm{C}$ & $\mathrm{C}$ & $\mathrm{E}$ \\
\hline Poker Jim Reservoir & 45.300910 & -106.342930 & C & & & & $\mathrm{C}$ & $E$ \\
\hline Red Rock Reservoir No. 1 & 45.296650 & -106.326320 & & & & C & $\mathrm{C}$ & $E$ \\
\hline Reservoir, $0.2 \mathrm{~km} \mathrm{~W}$ of Hansen Resel & 45.336840 & -106.369500 & $\mathrm{D}$ & & & B & C & $E$ \\
\hline Rocky Crossing Res. Nr. Diamond Bu & 45.251301 & -105.959518 & & $\mathrm{C}$ & & & $\mathrm{C}$ & $E$ \\
\hline
\end{tabular}


Appendix A. cont.

\begin{tabular}{lrc} 
& \multicolumn{1}{c}{$\begin{array}{c}\text { Descritude } \\
\text { Rocky Crossing Reservoir }\end{array}$} & Longitude \\
Slough Grass Reservoir & 45.252179 & -105.960803 \\
South Fork of Poker Jim Creek & 45.262410 & -105.954680 \\
Spring off N Taylor Creek & 45.336810 & -106.36488 \\
Spring, 0.3 miles ESE of Cow Creek F & 45.308365 & -106.240907 \\
Spring, 3.2 km on South Fork of Poke & 45.374360 & -106.41264 \\
Stag Rock Creek & 45.330117 & -106.18471 \\
Stocker Branch & 45.335517 & -106.326889 \\
Stocker Branch 2004 & 45.341480 & -106.312500 \\
Stocker Branch spring on O'dell Creel & 45.344694 & -106.321021 \\
Taylor Creek Reservoir & 45.226416 & -105.958564 \\
Timber Creek Basin Reservoir & 45.324880 & -106.403310 \\
Tongue River & 45.365696 & -106.49367 \\
Tongue River & 45.366777 & -106.491162 \\
Tongue River & 45.406356 & -106.457246 \\
Tongue River & 45.411542 & -106.457579 \\
Tooley Creek pools sec 19 Otter & 45.216450 & -106.266860 \\
Tooley Creek Seep & 45.211429 & -106.237619 \\
Tooley Creek Spring, 0.8 miles ESE c 45.215313 & -106.271235 \\
Upper Brian Spring & 45.404250 & -106.226310 \\
Wetland, 0.6 miles N of Yankee Sprin & 45.232677 & -105.903873 \\
Wilbur Creek Reservior & 45.598538 & -105.945966 \\
Wilbur Creek Spring & 45.590883 & -105.965029
\end{tabular}

$2004 \underline{2005} \underline{2006} 2008$ biointegrity indicators

$E \quad E \quad E$

C

D

C

C

B

D

B

$A$

B

C

C

A

D $\quad E$

C

C

C E

C $\quad$ B

B

B

C

B

D

E

E

E

E

E

E

C

D

C

B B

C C E

C $\quad C \quad C$

C $\mathrm{C}$ E

E

D D

D $\quad D \quad E$ 
Appendix B. Taxa lists and MMI metric information for selected macroinvertebrate sites sampled within the Ashland District Custer Forest.

\section{Montana Bioassessment Report}

Waterbody

05/13/2008

Total Number of Individuals in 488

Order:

Coleoptera

Coleoptera

Coleoptera

Coleoptera

Diptera

Diptera

Diptera

Diptera

Diptera

Diptera

Diptera

Diptera

Diptera

Diptera

Diptera

Diptera

Diptera

Diptera

Diptera

Diptera

Ephemeropt

Haplotaxida

Haplotaxida

Neotaeniogl

Non-Insect

Odonata

Plecoptera

Trichoptera

Trichoptera

Trombidifor

Veneroida
OTU name:

Agabus

Hydrobius

Hydroporus

Optioservus

Ceratopogoninae

Ceratopogoninae

Chironominae

Chironominae

Diamesinae

Dixa

Orthocladiinae

Orthocladiinae

Orthocladiinae

Orthocladiinae

Pericoma/Telmat

Prodiamesinae

Prodiamesinae

Tanypodinae

Tanypodinae

Tipula

Baetis

Oligochaeta

Oligochaeta

Hydrobiidae

Nematoda

Argia

Amphinemura

Hesperophylax

Psychoglypha

Acarina

Pisidiidae
FinalID

Agabus

Hydrobius

Hydroporus

Optioservus

Bezzia/Palpomyia

Culicoides

Micropsectra

Polypedilum

Pseudodiamesa

Dixa

Heleniella

Parametriocnemus

Paraphaenocladius

Thienemanniella

Pericoma

Odontomesa

Prodiamesa

Radotanypus

Thienemannimyia $\mathrm{Gr}$.

Tipula

Baetis tricaudatus

Lumbricina

Tubificidae

Amnicola limosa

Nematoda

Argia

Amphinemura banksi

Hesperophylax designatus

Psychoglypha

Lebertia

Pisidium
Collection Date:

\begin{tabular}{|c|c|c|c|}
\hline$\underset{9}{\text { Individuals }}$ & Tol Val: & $\begin{array}{c}\text { FFG: } \\
\text { PR }\end{array}$ & $\begin{array}{c}\text { Habit: } \\
\text { "CM(la), DI,SW(ad)" }\end{array}$ \\
\hline 5 & & & \\
\hline 6 & & PR & "CM (la), DI, SW \\
\hline 37 & 5 & $\mathrm{SC}$ & "CN/50\%, BU/50\%" \\
\hline 1 & 6 & $\mathrm{PR} / \mathrm{CG}$ & SP/BU/SW \\
\hline 9 & 6 & $\mathrm{PR} / \mathrm{CG}$ & SP/BU/SW \\
\hline 16 & 7 & CG/CF/PR & $\mathrm{BU} / \mathrm{CN} / \mathrm{SP}$ \\
\hline 1 & 7 & CG/CF/PR & $\mathrm{BU} / \mathrm{CN} / \mathrm{SP}$ \\
\hline 5 & 4 & CG & sp \\
\hline 1 & 4 & CG & sw \\
\hline 1 & & $\mathrm{CG} / \mathrm{SC}$ & SP/BU \\
\hline 2 & & $\mathrm{CG} / \mathrm{SC}$ & SP/BU \\
\hline 1 & & $\mathrm{CG} / \mathrm{SC}$ & $\mathrm{SP} / \mathrm{BU}$ \\
\hline 1 & & $\mathrm{CG} / \mathrm{SC}$ & $\mathrm{SP} / \mathrm{BU}$ \\
\hline 2 & 4 & CG & BU \\
\hline 7 & 5 & CG & $\mathrm{BU} / \mathrm{SP}$ \\
\hline 2 & 5 & CG & $\mathrm{BU} / \mathrm{SP}$ \\
\hline 21 & & PR & SP/BU \\
\hline 6 & & PR & SP/BU \\
\hline 7 & 4 & $\mathrm{SH}$ & $\mathrm{BU}$ \\
\hline 176 & 5 & CG & "SW/10\%, CN/90\%" \\
\hline 2 & 8 & CG & $\mathrm{BU}$ \\
\hline 1 & 8 & CG & BU \\
\hline 1 & & SC & $\mathrm{CN}$ \\
\hline 12 & 5 & unk & BU \\
\hline 2 & 7 & PR & $\mathrm{CN}$ \\
\hline 2 & 2 & $\mathrm{SH}$ & $\mathrm{CN}$ \\
\hline 123 & 3 & $\mathrm{SH}$ & $\mathrm{SP} / \mathrm{CN}$ \\
\hline 5 & 0 & CG & $\mathrm{SP}$ \\
\hline 1 & 5 & PR & "SW/10\%, CN/90\%" \\
\hline 23 & 8 & $\mathrm{CF}$ & $\mathrm{BU}$ \\
\hline
\end{tabular}


Appendix B. cont.

\section{Montana Bioassessment Report}

Waterbody Cow Creek above Res

Collection Date: 05/20/2004

Benthic Sample ID:17215

491

\section{Sample Taxa List}

\section{Order: \\ OTU name:}

FinallD

Basommato

Coleoptera

Coleoptera

Coleoptera

Coleoptera

Diptera

Diptera

Diptera

Diptera

Diptera

Diptera

Diptera

Diptera

Diptera

Diptera

Diptera

Diptera

Physa Physella

Agabus

Physella

Hydrobius

Optioservus

Oreodytes

Ceratopogoninae

Chironominae

Dicranota

Agabus

Hydrobius

Optioservus

Oreodytes

Bezzia/Palpomyia

Micropsectra

Dicranota

Dixa

Dixa

Orthocladiinae

Orthocladiinae

Orthocladiinae

Pedicia

Prodiamesinae

Tanypodinae

Tanypodinae

Haplotaxida

Baetis

Heleniella

Parametriocnemus

Tvetenia Bavarica Gr.

Pedicia

Prodiamesa

Radotanypus

Thienemannimyia Gr.

Tipula

Baetis tricaudatus

Lumbricina

Amnicola limosa

Trichoptera

Trichoptera

Trichoptera

Oligochaeta

Hydrobiidae

Cheumatopsyche

Hesperophylax

Cheumatopsyche

Hesperophylax designatus

Psychoglypha

Pisidium

\begin{tabular}{|c|c|c|c|}
\hline $\begin{array}{c}\text { Individuals } \\
53\end{array}$ & $\begin{array}{c}\text { Tol Val: } \\
\quad 8\end{array}$ & $\begin{array}{c}\text { FFG: } \\
\text { CG }\end{array}$ & $\begin{array}{l}\text { Habit: } \\
\text { CN }\end{array}$ \\
\hline 8 & 5 & PR & "CM(la), DI,SW(ad)" \\
\hline 3 & 5 & & \\
\hline 39 & 5 & $\mathrm{SC}$ & "CN/50\%, BU/50\%" \\
\hline 1 & 5 & PR & "CM (la), DI, SW \\
\hline 1 & 6 & $\mathrm{PR} / \mathrm{CG}$ & SP/BU/SW \\
\hline 1 & 7 & CG/CF/PR & $\mathrm{BU} / \mathrm{CN} / \mathrm{SP}$ \\
\hline 5 & 0 & PR & SP \\
\hline 6 & 4 & CG & sw \\
\hline 1 & & $\mathrm{CG} / \mathrm{SC}$ & SP/BU \\
\hline 3 & & $\mathrm{CG} / \mathrm{SC}$ & SP/BU \\
\hline 1 & & CG/SC & SP/BU \\
\hline 2 & 6 & PR & BU \\
\hline 2 & 5 & CG & $\mathrm{BU} / \mathrm{SP}$ \\
\hline 9 & & PR & SP/BU \\
\hline 3 & & PR & SP/BU \\
\hline 6 & 4 & $\mathrm{SH}$ & $\mathrm{BU}$ \\
\hline 279 & 5 & CG & "SW/10\%, CN/90\%" \\
\hline 3 & 8 & CG & BU \\
\hline 1 & & $\mathrm{sC}$ & $\mathrm{CN}$ \\
\hline 3 & 5 & $\mathrm{CF}$ & $\mathrm{CN}$ \\
\hline 49 & 3 & $\mathrm{SH}$ & $\mathrm{SP} / \mathrm{CN}$ \\
\hline 9 & 0 & CG & SP \\
\hline 3 & 8 & CF & $B U$ \\
\hline
\end{tabular}


Appendix B. cont.

\section{Montana Bioassessment Report}

Waterbody

05/20/2005

\section{Total Number of Individuals in}

\section{Order: OTU name: FinalID}

Smittia/Psuedosmittia

Physella

Agabus

Agabus sp 2

Hydrobius

Hydroporus

Optioservus

Bezzia/Palpomyia

Ceratopogon

Culicoides

Micropsectra

Paratendipes

Polypedilum

Pseudodiamesa

Dixa

Empididae

Heleniella

Parametriocnemus

Paraphaenocladius

Thienemanniella

Pericoma

Odontomesa

Prodiamesa

Radotanypus

Thienemannimyia Gr.

Tipula

Baetis tricaudatus

Lumbricina

Tubificidae

Amnicola limosa

Nematoda

Amphinemura banksi

Hesperophylax designatus

Psychoglypha

Lebertia

Pisidium
569

Individuals Tol Val: FFG: Habit:

\begin{tabular}{|c|c|c|c|}
\hline \multicolumn{4}{|l|}{1} \\
\hline 1 & 8 & CG & $\mathrm{CN}$ \\
\hline 8 & 5 & PR & "CM(la), DI,SW(ad)" \\
\hline 9 & 5 & & \\
\hline \multicolumn{4}{|l|}{5} \\
\hline 6 & & PR & "CM (la), DI, SW \\
\hline 102 & 5 & SC & "CN/50\%, BU/50\%" \\
\hline 1 & 6 & PR/CG & SP/BU/SW \\
\hline 1 & 6 & PR/CG & SP/BU/SW \\
\hline 4 & 6 & PR/CG & SP/BU/SW \\
\hline 8 & 7 & CG/CF/PR & $\mathrm{BU} / \mathrm{CN} / \mathrm{SP}$ \\
\hline 2 & 7 & CG/CF/PR & $\mathrm{BU} / \mathrm{CN} / \mathrm{SP}$ \\
\hline 1 & 7 & CG/CF/PR & $\mathrm{BU} / \mathrm{CN} / \mathrm{SP}$ \\
\hline 1 & 4 & CG & $\mathrm{sp}$ \\
\hline 1 & 4 & CG & SW \\
\hline 1 & 6 & PR & SP \\
\hline 1 & & CG/SC & SP/BU \\
\hline 2 & & CG/SC & SP/BU \\
\hline 1 & & CG/SC & SP/BU \\
\hline 1 & & $\mathrm{CG} / \mathrm{SC}$ & SP/BU \\
\hline 1 & 4 & CG & $\mathrm{BU}$ \\
\hline 6 & 5 & CG & $\mathrm{BU} / \mathrm{SP}$ \\
\hline 2 & 5 & CG & $\mathrm{BU} / \mathrm{SP}$ \\
\hline 31 & & PR & SP/BU \\
\hline 6 & & PR & SP/BU \\
\hline 6 & 4 & $\mathrm{SH}$ & $\mathrm{BU}$ \\
\hline 149 & 5 & CG & "SW/10\%, CN/90\%" \\
\hline 1 & 8 & CG & $\mathrm{BU}$ \\
\hline 1 & 8 & CG & $\mathrm{BU}$ \\
\hline 1 & & SC & $\mathrm{CN}$ \\
\hline 7 & 5 & unk & $\mathrm{BU}$ \\
\hline 1 & 2 & $\mathrm{SH}$ & $\mathrm{CN}$ \\
\hline 146 & 3 & $\mathrm{SH}$ & $\mathrm{SP} / \mathrm{CN}$ \\
\hline 5 & 0 & CG & SP \\
\hline 1 & 5 & PR & "SW/10\%, CN/90\%" \\
\hline 48 & 8 & CF & $\mathrm{BU}$ \\
\hline
\end{tabular}


Appendix B. cont.

\section{Montana Bioassessment Report}

\begin{tabular}{|c|c|c|c|c|c|c|}
\hline Waterbody & Cow & reek above Res t3 & Collection Da & & 05/19/200 & \\
\hline Collection & MTkic & 500 & Total Numk & of Indivi & uals 319 & \\
\hline $\begin{array}{l}\text { Order: } \\
\text { Coleoptera }\end{array}$ & $\begin{array}{l}\text { OTU name: } \\
\text { Agabus }\end{array}$ & $\begin{array}{l}\text { FinalID } \\
\text { Agabus }\end{array}$ & Individuals & Tol Val: & $\begin{array}{l}\text { FFG: } \\
\text { PR }\end{array}$ & $\begin{array}{c}\text { Habit: } \\
\text { "CM(la), DI,SW(ad)" }\end{array}$ \\
\hline Coleoptera & Cymbiodyta & Cymbiodyta & 1 & & unk & unk \\
\hline Coleoptera & Laccobius & Laccobius & 1 & & unk & unk \\
\hline Coleoptera & Optioservus & Optioservus & 52 & 5 & SC & "CN/50\%, BU/50\%" \\
\hline Diptera & Ceratopogoninae & Culicoides & 1 & 6 & $\mathrm{PR} / \mathrm{CG}$ & SP/BU/SW \\
\hline Diptera & Chironominae & Phaenopsectra & 3 & 7 & CG/CF/PR & $\mathrm{BU} / \mathrm{CN} / \mathrm{SP}$ \\
\hline Diptera & Chironominae & Polypedilum & 2 & 7 & CG/CF/PR & $\mathrm{BU} / \mathrm{CN} / \mathrm{SP}$ \\
\hline Diptera & Chironominae & Tanytarsus & 2 & 7 & CG/CF/PR & $\mathrm{BU} / \mathrm{CN} / \mathrm{SP}$ \\
\hline Diptera & Pedicia & Pedicia & 4 & 6 & PR & $\mathrm{BU}$ \\
\hline Diptera & Prodiamesinae & Prodiamesa & 7 & 5 & CG & $\mathrm{BU} / \mathrm{SP}$ \\
\hline Diptera & Tanypodinae & Radotanypus & 24 & & PR & SP/BU \\
\hline Diptera & Tanypodinae & Thienemannimyia Gr. & 2 & & PR & SP/BU \\
\hline Diptera & Tipula & Tipula & 10 & 4 & $\mathrm{SH}$ & $\mathrm{BU}$ \\
\hline Ephemeropt & Baetis & Baetis tricaudatus & 103 & 5 & CG & "SW/10\%, CN/90\%" \\
\hline Haplotaxida & Oligochaeta & Tubificidae & 3 & 8 & CG & $\mathrm{BU}$ \\
\hline Odonata & Argia & Argia & 2 & 7 & PR & $\mathrm{CN}$ \\
\hline Trichoptera & Hesperophylax & Hesperophylax designatus & 101 & 3 & $\mathrm{SH}$ & $\mathrm{SP} / \mathrm{CN}$ \\
\hline Waterhos & Cow & eek above Res t4 & & & Collect & Date: \\
\hline
\end{tabular}

05/12/2008

Total Number of Individuals 600

\begin{tabular}{|c|c|c|c|c|c|c|}
\hline Order: & OTU name: & $\begin{array}{l}\text { FinalID } \\
\text { Smittia/Psuedosmittia }\end{array}$ & $\underset{1}{\text { Individuals }}$ & Tol Val: & FFG: & Habit: \\
\hline Basommato & Physa_Physella & Physella & 1 & 8 & CG & $\mathrm{CN}$ \\
\hline Coleoptera & Hydrobius & Hydrobius & 5 & & & \\
\hline Coleoptera & Hydroporus & Hydroporus & 6 & & PR & "CM (la), DI, SW \\
\hline Coleoptera & Optioservus & Optioservus & 246 & 5 & SC & "CN/50\%, BU/50\%" \\
\hline Diptera & Caloparyphus & Caloparyphus & 1 & 7 & CG & SP \\
\hline Diptera & Ceratopogoninae & Bezzia/Palpomyia & 2 & 6 & $\mathrm{PR} / \mathrm{CG}$ & SP/BU/SW \\
\hline Diptera & Chelifera_Metach & Chelifera & 2 & 5 & unk & $\mathrm{SP}$ \\
\hline Diptera & Chironominae & Micropsectra & 12 & 7 & CG/CF/PR & $\mathrm{BU} / \mathrm{CN} / \mathrm{SP}$ \\
\hline Diptera & Chironominae & Polypedilum & 2 & 7 & CG/CF/PR & $\mathrm{BU} / \mathrm{CN} / \mathrm{SP}$ \\
\hline Diptera & Diamesinae & Pseudodiamesa & 3 & 4 & CG & $\mathrm{sp}$ \\
\hline Diptera & Dicranota & Dicranota & 4 & 0 & PR & SP \\
\hline Diptera & Dixa & Dixa & 2 & 4 & CG & SW \\
\hline Diptera & Orthocladiinae & Heleniella & 1 & & CG/SC & SP/BU \\
\hline Diptera & Orthocladiinae & Parametriocnemus & 5 & & CG/SC & SP/BU \\
\hline Diptera & Orthocladiinae & Paraphaenocladius & 1 & & CG/SC & SP/BU \\
\hline Diptera & Orthocladiinae & Thienemanniella & 2 & & CG/SC & SP/BU \\
\hline Diptera & Pericoma/Telmat & Pericoma & 4 & 4 & CG & $\mathrm{BU}$ \\
\hline Diptera & Prodiamesinae & Odontomesa & 7 & 5 & CG & $\mathrm{BU} / \mathrm{SP}$ \\
\hline Diptera & Prodiamesinae & Prodiamesa & 2 & 5 & CG & $\mathrm{BU} / \mathrm{SP}$ \\
\hline Diptera & Tanypodinae & Radotanypus & 23 & & PR & SP/BU \\
\hline Diptera & Tanypodinae & Thienemannimyia Gr. & 3 & & PR & SP/BU \\
\hline Diptera & Tipula & Tipula & 5 & 4 & $\mathrm{SH}$ & $\mathrm{BU}$ \\
\hline Ephemeropt & Baetis & Baetis tricaudatus & 120 & 5 & CG & "SW/10\%, CN/90\%" \\
\hline Haplotaxida & Oligochaeta & Lumbricina & 2 & 8 & CG & $\mathrm{BU}$ \\
\hline Haplotaxida & Oligochaeta & Tubificidae & 2 & 8 & CG & $\mathrm{BU}$ \\
\hline Neotaeniogl & Hydrobiidae & Amnicola limosa & 2 & & SC & $\mathrm{CN}$ \\
\hline Non-Insect & Nematoda & Nematoda & 21 & 5 & unk & $\mathrm{BU}$ \\
\hline Odonata & Argia & Argia & 2 & 7 & PR & $\mathrm{CN}$ \\
\hline Plecoptera & Amphinemura & Amphinemura banksi & 5 & 2 & $\mathrm{SH}$ & $\mathrm{CN}$ \\
\hline Trichoptera & Hesperophylax & Hesperophylax designatus & 68 & 3 & $\mathrm{SH}$ & $\mathrm{SP} / \mathrm{CN}$ \\
\hline Trichoptera & Psychoglypha & Psychoglypha & 5 & 0 & CG & $\mathrm{SP}$ \\
\hline Trombidifor & Acarina & Lebertia & 1 & 5 & PR & "SW/10\%, CN/90\%" \\
\hline Veneroida & Pisidiidae & Pisidium & 32 & 8 & $\mathrm{CF}$ & $\mathrm{BU}$ \\
\hline
\end{tabular}


Appendix B. cont.

\section{Montana Bioassessment Report}

$\begin{array}{ll}\text { Waterbody } & \text { Cow Creek below Res t1 } \\ \text { Collection } & \text { MTkick500 }\end{array}$

Collection Date: 05/20/04

Sample Taxa List

$\begin{array}{lll}\text { Order: } & \text { OTU name: } & \text { FinalID } \\ \text { Amphipoda } & \text { Hyalella } & \text { Hyalella azteca } \\ \text { Basommato } & \text { Physa_Physella } & \text { Physella } \\ \text { Basommato } & \text { Planorbidae } & \text { Gyraulus parvus } \\ \text { Coleoptera } & \text { Agabus } & \text { Agabus } \\ \text { Coleoptera } & \text { Hydrobius } & \text { Hydrobius } \\ \text { Coleoptera } & \text { Optioservus } & \text { Optioservus } \\ \text { Coleoptera } & \text { Oreodytes } & \text { Oreodytes } \\ \text { Coleoptera } & \text { Tropisternus } & \text { Tropisternus } \\ \text { Diptera } & \text { Ceratopogoninae } & \text { Bezzia } \\ \text { Diptera } & \text { Chironominae } & \text { Micropsectra } \\ \text { Diptera } & \text { Chironominae } & \text { Polypedilum } \\ \text { Diptera } & \text { Orthocladiinae } & \text { Parametriocnemus } \\ \text { Diptera } & \text { Orthocladiinae } & \text { Paraphaenocladius } \\ \text { Diptera } & \text { Tanypodinae } & \text { Radotanypus } \\ \text { Diptera } & \text { Tanypodinae } & \text { Thienemannimyia Gr. } \\ \text { Diptera } & \text { Tipula } & \text { Tipula } \\ \text { Ephemeropt } & \text { Baetis } & \text { Baetis tricaudatus } \\ \text { Haplotaxida } & \text { Oligochaeta } & \text { Tubificidae } \\ \text { Non-Insect } & \text { Turbellaria } & \text { Turbellaria } \\ \text { Not in I.T.I.S } & \text { Acarina } & \text { Acari } \\ \text { Trichoptera } & \text { Cheumatopsyche } & \text { Cheumatopsyche } \\ \text { Trichoptera } & \text { Hesperophylax } & \text { Hesperophylax designatus } \\ \text { Trichoptera } & \text { Psychoglypha } & \text { Psychoglypha } \\ \text { Veneroida } & \text { Pisidiidae } & \text { Pisidium }\end{array}$

$\begin{array}{cccc}\text { Individuals } & \text { Tol Val: } & \text { FFG: } & \text { Habit: } \\ 10 & 8 & \text { CG } & \text { SW/SP } \\ 123 & 8 & \text { CG } & \text { CN } \\ 22 & 6 & \text { CG } & \text { CN } \\ 8 & 5 & \text { PR } & \text { "CM(la), DI,SW(ad)" } \\ 3 & 5 & \text { PR } & \text { "CM (la), DI, SW } \\ 22 & 5 & \text { SC } & \text { "CN/50\%, BU/50\%" } \\ 1 & 5 & \text { PR } & \text { "CM (la), DI, SW } \\ 2 & & \text { PR } & \text { "CN,SP,CM(la), } \\ 12 & 6 & \text { PR/CG } & \text { SP/BU/SW } \\ 6 & 7 & \text { CG/CF/PR } & \text { BU/CN/SP } \\ 5 & 7 & \text { CG/CF/PR } & \text { BU/CN/SP } \\ 3 & & \text { CG/SC } & \text { SP/BU } \\ 2 & & \text { CG/SC } & \text { SP/BU } \\ 9 & & \text { PR } & \text { SP/BU } \\ 3 & & \text { PR } & \text { SP/BU } \\ 6 & 4 & \text { SH } & \text { BU } \\ 21 & 5 & \text { CG } & \text { "SW/10\%, CN/90\%" } \\ 7 & 8 & \text { CG } & \text { BU } \\ 32 & 4 & \text { CG/PR } & \text { SP } \\ 4 & 5 & \text { PR } & \text { "SW/10\%, CN/90\%" } \\ 8 & 5 & \text { CF } & \text { CN } \\ 25 & 3 & \text { SH } & \text { SP/CN } \\ 1 & 0 & \text { CG } & \text { SP } \\ 5 & 8 & \text { CF } & \text { BU }\end{array}$


Appendix B. cont.

\section{Montana Bioassessment Report}

Waterbody Cow Creek below Res t2

Total Number of Individuals in 594

Collection Date:

$05 / 20 / 2004$

\section{Sample Taxa List}

\section{Order: \\ OTU name:}

Amphipoda

Arhynchobd

Arhynchobd

Basommato

Coleoptera

Coleoptera

Coleoptera

Diptera

Diptera

Diptera

Diptera

Diptera

Diptera

Diptera

Diptera

Diptera

Diptera

Diptera

Diptera

Diptera

Diptera

Diptera

Diptera

Diptera

Diptera

Ephemeropt

Haplotaxida

Odonata

Trichoptera

Trichoptera

Trombidifor

Veneroida
Hyalella

Erpobdellidae

Glossophonidae

Physa_Physella

Agabus

Hydrobius

Optioservus

Ceratopogoninae

Ceratopogoninae

Ceratopogoninae

Ceratopogoninae

Ceratopogoninae

Chironominae

Chironominae

Chironominae

Chironominae

Chironominae

Diamesinae

Dicranota

Orthocladiinae

Simuliidae

Tabanidae

Tabanidae

Tanypodinae

Tanypodinae

Baetis

Oligochaeta

Argia

Hesperophylax

Limnephilus

Acarina

Pisidiidae
FinalID

Pytchoptera

Hyalella azteca

Erpobdellidae

Glossophona complanata

Physella gyrina

Agabus

Hydrobius

Optioservus

Athrichopogon

Bezzia

Culicoides

Dasyhelaea

Probezzia

Micropsectra

Polypedilum

Rheotanytarsus

Tanytarsus

Tribelos

Pseudodiamesa

Dicranota

Orthocladius

Simulium

Chrysops

Tabanus

Radotanypus

Thienemannimyia Gr.

Baetis tricaudatus

Tubificidae

Argia

Hesperophylax designatus

Limnephilus

Lebertia

Pisidium
Individuals Tol Val: FFG: Habit:

Eukiefferiella claripennis grp 1

1

69

10

10

33

4

3

44

11

\begin{tabular}{|c|c|c|}
\hline 8 & CG & SW/SP \\
\hline 8 & PR & SW \\
\hline 8 & PR & SW \\
\hline 8 & CG & $\mathrm{CN}$ \\
\hline 5 & PR & "CM(la), DI,SW(ad)" \\
\hline 5 & SC & "CN/50\%, BU/50\%" \\
\hline 6 & $\mathrm{PR} / \mathrm{CG}$ & SP/BU/SW \\
\hline 6 & PR/CG & SP/BU/SW \\
\hline 6 & $\mathrm{PR} / \mathrm{CG}$ & SP/BU/SW \\
\hline 6 & PR/CG & SP/BU/SW \\
\hline 7 & CG/CF/PR & $\mathrm{BU} / \mathrm{CN} / \mathrm{SP}$ \\
\hline 7 & CG/CF/PR & $\mathrm{BU} / \mathrm{CN} / \mathrm{SP}$ \\
\hline 7 & CG/CF/PR & $\mathrm{BU} / \mathrm{CN} / \mathrm{SP}$ \\
\hline 7 & CG/CF/PR & $\mathrm{BU} / \mathrm{CN} / \mathrm{SP}$ \\
\hline 7 & CG/CF/PR & $\mathrm{BU} / \mathrm{CN} / \mathrm{SP}$ \\
\hline 4 & CG & $\mathrm{sp}$ \\
\hline \multirow[t]{2}{*}{0} & PR & SP \\
\hline & CG/SC & SP/BU \\
\hline 6 & CF & $\mathrm{CN}$ \\
\hline 10 & PR & SP \\
\hline \multirow[t]{3}{*}{10} & PR & SP \\
\hline & PR & SP/BU \\
\hline & PR & SP/BU \\
\hline 5 & CG & "SW/10\%, CN/90\%" \\
\hline 8 & CG & $B U$ \\
\hline 7 & PR & $\mathrm{CN}$ \\
\hline 3 & $\mathrm{SH}$ & $\mathrm{SP} / \mathrm{CN}$ \\
\hline 3 & $\mathrm{SH}$ & $\mathrm{CM} / \mathrm{SP}$ \\
\hline 5 & PR & "SW/10\%, CN/90\%" \\
\hline 8 & CF & $B U$ \\
\hline
\end{tabular}


Appendix C. Northwestern Great Plains Perennial Spring Ecological Description (Stagliano 2005).

\section{Northwestern Great Plains Perennial Spring Ecosystem}

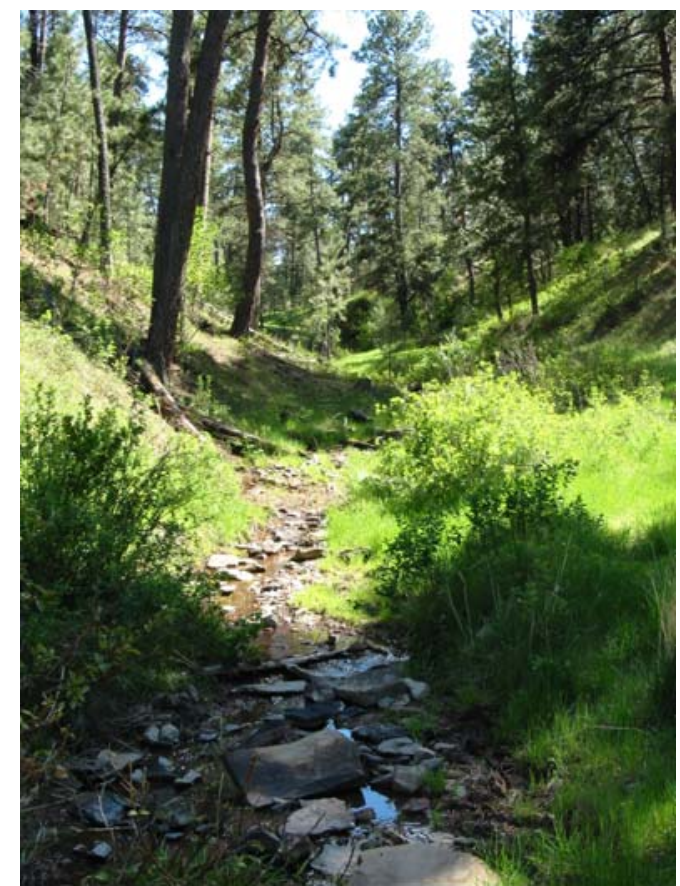

Figure A. Cow Creek (S005) reference spring example Custer National Forest.

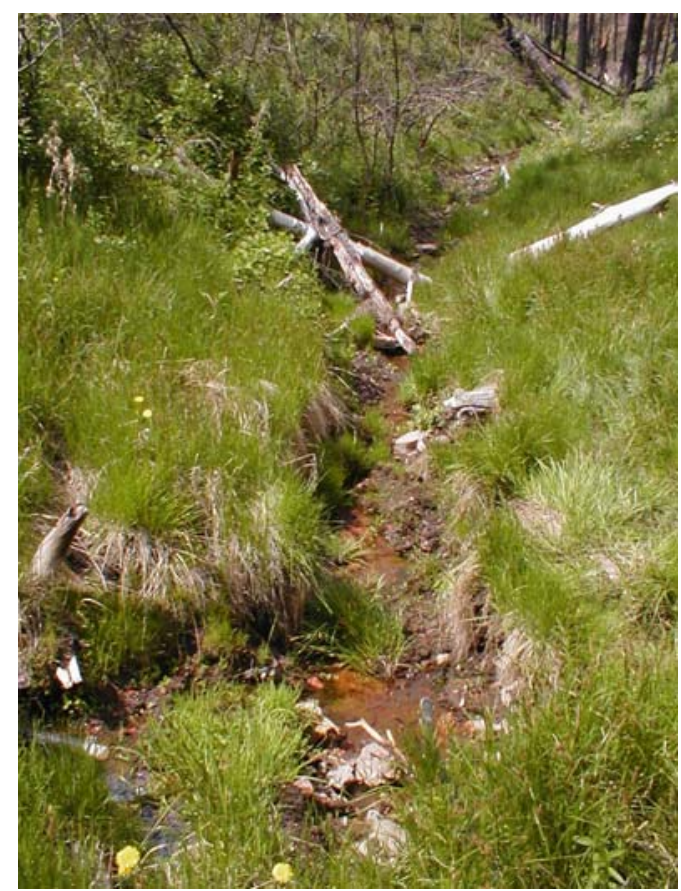

Figure B. Little Brian Creek Spring (S005) a slightly Impaired example within the Custer National Forest.

\section{Aquatic Ecological System Type: S005}

\section{Ecological Description}

\section{Summary:}

This ecosystem is found in the moderate elevation $(1000-1600 \mathrm{~m})$, upland hill areas of the Northwestern Great Plains. It occurs as small (0.2-2m wetted width) perennial, headwater springs with low to moderate gradient flowing through sedimentary geology. Benthic habitats in undisturbed areas are typically long riffle/ run reaches dominated by shale cobbles and gravel with some woody debris (see Figures above).

\section{Environment:}

Throughout its Montana range, it occurs in seeps and springs within the Custer National Forest, Wolf Mountains and the higher elevation Ponderosa pine forests of the Powder River Basin. Surface topography usually has a moderate gradient or sometimes undulating or hummocky. Disturbance by cattle is widespread, as these springs often represent the only water source in the uplands.

Fish Community: This is a fishless system.

Macroinvertebrate Community: The reference condition ecological system (S005) indicator macroinvertebrates include the midges - Odontomesa, Radotanypus, Heleniella, Pseudodiamesa, diptera - Tipula, Dicranota, Ormosia, Pedicia, the snails - Hydrobiidae and Physa; the MayflyBaetis tricaudatus, the caddisfly-Hesperophylax designatus, the Beetles-Oreodytes, Optioservus and Hydroporus, and the damselfly larva- Argia. Sediment impaired and cattle degraded springs will quickly lose the mayfly, caddisfly, and dipteran species (above), and form a community dominated by tolerant midges, biting dipteran larvae (Ceratopogonidae) and air breathing beetles. 


\section{Range:}

The Northwestern Great Plains Perennial Spring Community type has been collected in the Custer National Forest, Wolf Mountains and the higher elevation Ponderosa pine forests of the Powder River Basin.

\section{Management:}

Grazing and livestock use around these springs should be limited to a stock tank; immediate spring areas should be fenced to avoid cattle intrusions. Soils adjacent to the springs are often waterlogged and are easily trampled and hummocked by livestock, causing severe streambed degradation, sedimentation, bank failure and siltation downstream.

Global Rank: GU

State Rank: S3

\section{Global Rank Comments:}

The number of occurrences is unknown. In Montana, this ecosystem is reported from 50 site visits within the Custer National Forest Ashland District, but only three of these sites contained a high-quality, fully functional S005 community (Stagliano 2004 \& 2005, this study). In a similar ecological type, the caddisfly, Hesperophylax designatus was also found to be an indicator species of perennial springs in the Glass Mountains of the Great Basin (UT) in a 1994 survey (Myers 1995). Therefore, this ecosystem may be widespread, but because of the limited occurrence of high integrity sites in Montana, should probably be evaluated for long-term monitoring, and restoration of degraded sites. 